\title{
Assessment of plate-end debonding design provisions for RC beams strengthened with FRP
}

\author{
Mohammed A. Al-Saawani ${ }^{\mathrm{a}}$ (D) Ahmed K. El-Sayed $^{\mathrm{a} *}$ (D), Abdulaziz I. Al-Negheimish ${ }^{\mathrm{a}}$ \\ a Department of Civil Engineering, College of Engineering, King Saud University, Riyadh, Kingdom of Saudi Arabia. \\ E-mail: malsaawani@ksu.edu.sa, ahelsayed@ksu.edu.sa,negaimsh@ksu.edu.sa \\ * Corresponding author
}

http://dx.doi.org/10.1590/1679-78255920

\begin{abstract}
Despite the enhancement in the flexural capacity of reinforced concrete (RC) members externally strengthened with fiber reinforced polymer (FRP) composites, debonding of the FRP from the concrete substrate at its ends is a major concern. This premature failure mostly occurs at a low fraction of the FRP rupture strain, thus compromises the effectiveness of FRP-strengthening. This paper presents a review on plate-end (PE) debonding as a critical failure mode in FRP-strengthened beams. The available models for predicting this mode of failure are also presented and assessed against experimental database established from previous studies. The precautions recommended by the relevant design codes to prevent PE debonding are also discussed and assessed. Based on the assessment, several conclusions are emphasized, including the inaccuracy in predictions of PE debonding given by most available models when compared with the experimental database and the inconsistency among these models. The assessment also revealed that the precautions recommended by most of the design codes are not adequate to prevent PE debonding.
\end{abstract}

\section{Keywords:}

assessment, concrete beams, design models, FRP composites, plate-end debonding, strengthening

\section{Graphical Abstract}

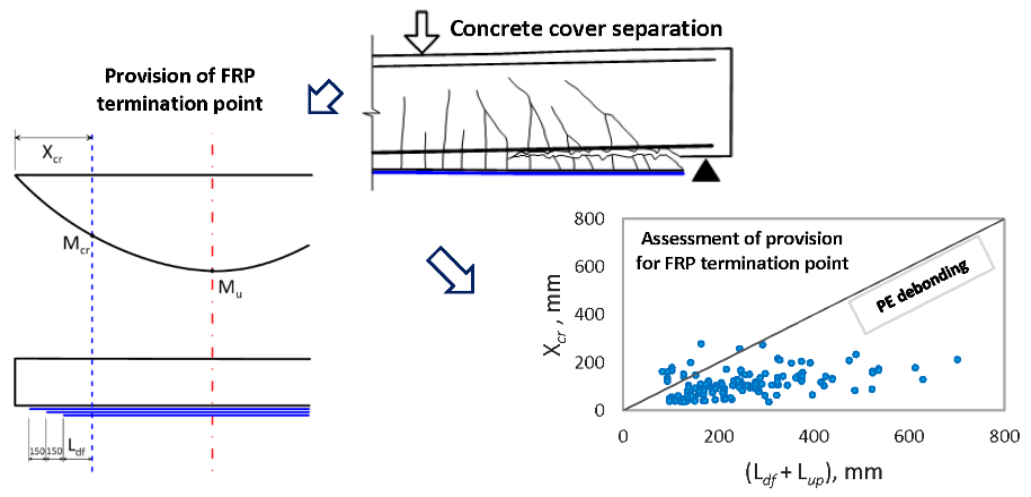




\section{INTRODUCTION}

Strengthening of reinforced concrete (RC) beams in flexure with fiber-reinforced polymer (FRP) plates/sheets externally bonded (EB) to the tension face of concrete is an excellent alternative to traditional strengthening methods. This is attributed to the superior properties of FRP materials such as light weight, high tensile strength, and corrosion resistance.

Numerous experimental and analytical investigations have been carried out [Arduini et al. 1997; Ross et al. 1999; Fanning and Kelly 2001; Teng et al. 2003; Al-Negheimish et al. 2012], which resulted in more understanding of the behavior of FRP-strengthened RC members. However, premature debonding of the EB FRP from the concrete substrate is a major drawback, which does not allow for an effective utilization of FRP-strengthening. Debonding at the FRP plate end (PE debonding) or at locations within the beam induced by an intermediate crack (IC debonding) are the two common debonding failure modes in FRP-strengthened RC beams [Smith and Teng 2003; Teng and Yao 2007; Yao and Teng 2007]. In simply supported beams, IC debonding normally initiates at the high moment region due to flexural or flexural-shear cracks and then propagates toward the plate end [Teng et al. 2003; Al-Negheimish et al. 2012; Yao et al. 2002]. Such failure is critical for beams with relatively long shear-spans or where the end-peeling has been effectively mitigated [ACl 440.2 2017]. Such failure mode has been extensively investigated in the literature [e.g., Teng et al. 2003; Al-Negheimish et al. 2012] which led to increased understanding of its mechanism and the development of reliable prediction models. On the other hand, PE debonding initiates by high interfacial stresses at the FRP plate end and then propagates toward the mid-span of the beam [Yao and Teng 2007; Smith and Teng 2002a; Smith and Teng 2002b; Lu et al. 2005]. It occurs in a very brittle manner (mostly before the yielding of tension steel) which is not preferred in design as the governing failure mode.

Research studies have been conducted to understand the factors that cause PE debonding and develop models for its prediction. Nevertheless, the mechanism of this debonding failure is complicated and still not fully understood, making it difficult for engineers to consistently and accurately estimate the capacity of FRP-strengthened beams and the anticipated failure type. This explains why most of the design codes and guidelines provide certain precautions to avoid the occurrence of PE debonding. Increasing the length of the FRP plate does not increase the bonding strength because there is an effective length beyond which bonding strength does not increase [Teng et al. 2001]. Therefore, effective solutions to prevent or delay debonding failures are important to achieve higher levels of FRP utilization prior to failure and establish more confidence in the use of FRP composites for strengthening applications. Many design codes and guidelines [ACI 440.2, 2017; International Federation for Structural Concrete, 2001, GB-50608, 2010; Concrete Society 2012; CNR, 2013] emphasize on the need for an anchorage method at the termination points of the FRP plate to prevent PE debonding. In fact, different techniques have been proposed to anchor the FRP reinforcement to the concrete beam instead of relying solely on the bond to transfer the stresses between the concrete substrate and FRP [Smith and Teng 2003, Matthys 2000; Brena et al. 2003; Kotynia et al. 2008; Rosenboom and Rizkalla 2008; Orton et al. 2008; Zhang et al. 2012; Kalfat et al. 2013; Lee and Lopez 2016; Chen and Teng 2001; Yao 2004; Lu et al. 2007].

This paper presents a review of research studies available in the literature related to PE debonding failure and gives an overview of the relevant prediction models. Evaluation of such models is carried out against experimental database established from the literature. The paper also presents the code provisions recommended to avoid PE debonding. Those provisions are also evaluated using the constructed experimental database. Mitigation of PE debonding of FRP reinforcement using available end anchorage systems is briefly discussed.

\section{FAILURE MECHANISMS}

Several failure modes for RC beams strengthened in flexure with FRP composites have been observed from different experimental investigations [Yao and Teng 2007; Teng et al. 2002; Oehlers et al. 2004]. These failure modes are (1) concrete crushing, (2) FRP rupture, (3) shear failure, (4) concrete cover separation, (5) plate-end interfacial debonding, and (6) intermediate flexural or flexural-shear crack-induced interfacial debonding (known as IC debonding). Failure of the strengthened beams by crushing of concrete, FRP rupture, or shear failure of the concrete section is categorized as composite action failure modes. The other failure mechanisms are considered premature failure modes because they occur suddenly before utilizing the full strength of the FRP materials. Debonding of the FRP plates from the concrete substrate is a major concern which controls the overall behavior and strength of the FRP-strengthened RC members [Spadea et al. 1998, Mazzotti et al. 2008]. Since the adhesive strength is much higher than the tensile strength of concrete, debonding always occurs within the concrete itself with removal of a layer of concrete of a thickness ranging from few millimeters to the whole concrete cover. 
Debonding failure may initiate at the toe of flexural or flexural-shear crack in the high moment region, and then propagate along the direction of decreasing moment towards one of the FRP plate ends. This debonding failure mode is commonly referred to as intermediate crack (IC) induced interfacial debonding [Fanning and Kelly 2001; Teng et al. 2003; Al-Negheimish et al. 2012, Lu et al. 2007, Wu and Niu 2000; Chen et al. 2006]. Observations suggest that IC debonding is more likely to dominate when the distance between the FRP plate end and the support is relatively small [Yao and Teng 2007]. In addition, for slender RC beams having high shear span/depth ratios, IC debonding mostly initiates at sections of high bending moment away from the plate ends. A more brittle failure is the plate-end (PE) debonding, which initiates at the FRP plate end and propagates towards the midspan of the beam. This mode of failure occurs due to the high interfacial and normal stresses developed at the plate end region. The stress state of an element at the plate end region is shown in Figure 1, where $\tau$ and $\sigma_{y}$ represent the interfacial shear stress and transverse normal stress, respectively. The longitudinal normal stress is denoted as $\sigma_{x}$ as shown in Figure 1 [Smith and Teng 2002a]. Debonding at the end of EB FRP can be further divided into two different modes, which are: (a) concrete cover separation and (b) plate-end interfacial debonding. These plate-end debonding failures are discussed in the following subsections.

\subsection{Concrete cover separation (CCS)}

Concrete cover separation is the most common PE debonding failure, which initiates due to interfacial shear and normal stresses at the critical end of the FRP. The mechanism of CCS is related to several factors, including the concrete cover thickness, the number and size of tension steel bars, and the moment and shear force at the FRP plate end [Smith and Teng 2003; Teng and Yao 2007; Yao and Teng 2007]. For strengthened beams with FRP terminated close to

Concrete element

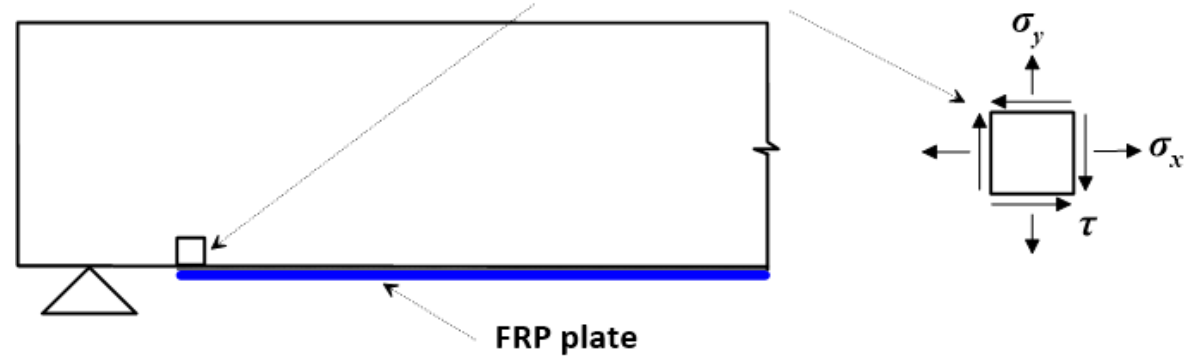

Figure 1. Stress state of an element at the plate end region [Smith and Teng 2002a].

the support, CCS occurs after the formation of shear cracks [Achintha and Burgoyne 2011]. Widening of the shear crack under loading increases the interfacial shear stresses. Also, shear cracks are generally associated with relative vertical displacement between the two crack surfaces. This relative displacement increases the transverse normal tensile stress acting on the concrete layer between FRP and the embedded tensile steel reinforcement [International Federation for Structural Concrete, 2001]. The combined effect of the increased normal tensile stress and the increased interfacial stress leads finally to the formation of horizontal splitting cracks at the level of the tensile reinforcing steel bars and separation of the concrete cover. For strengthened beams with FRP terminated away from the support, CCS occurs after the formation of inclined cracks that develop at the plate end and propagate in the beam towards the tension steel bars. Once the cracks reach the level of the steel bars, they propagate horizontally causing splitting of the concrete cover [Achintha and Burgoyne 2011]. The CCS failure is schematically drawn in Fig. 2(a) and illustrated by photograph in Fig. 2(b) [Al-Saawani et al. 2015]. 


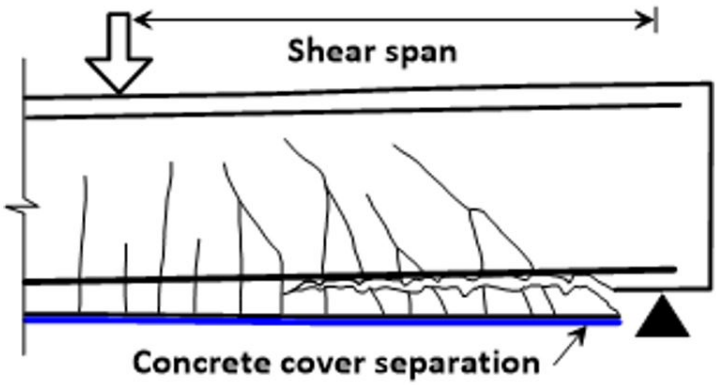

(a) Schematic representation of CCS.

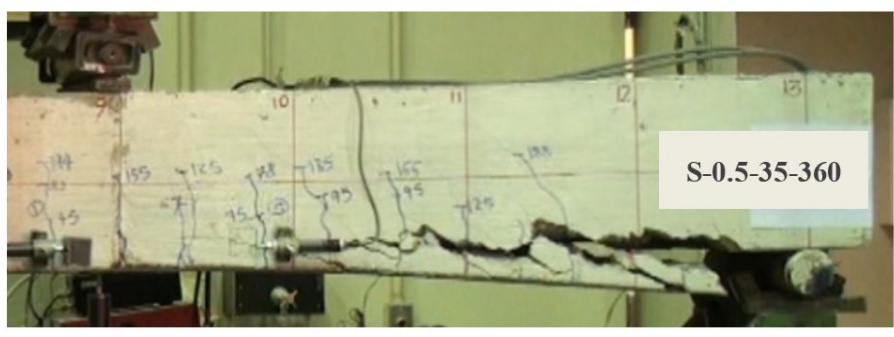

(b) Failure by CCS, adopted from [Al-Saawani et al. 2015].

Figure 2. Failure by concrete cover separation in FRP-strengthened RC beams.

\subsection{Plate-end interfacial debonding}

Plate-end interfacial debonding occurs due to higher interfacial shear stresses near the FRP plate end, which exceed the tensile strength of the concrete substrate. Debonding initiates at the end of the FRP plate and propagates along the interface of concrete and FRP towards the middle of the beam without reaching the level of tension steel reinforcement, as shown in Fig. 3(a). This debonding failure is less common than CCS and most likely to occur when the FRP plate width is significantly narrower than the beam width [Yao and Teng 2007]. Fig. 3(b) shows a picture of FRP-strengthened beam failed by PE interfacial debonding [Teng and Chen 2007].

\section{PREVIOUS STUDIES ON PLATE END DEBONDING}

Plate-end debonding is influenced by different parameters related to the geometry of the RC beam and the properties of the internal and external reinforcements. Such parameters include the thickness of concrete cover; the section geometry; concrete strength; the amount of tension steel reinforcement; FRP plate width, thickness, and modulus of elasticity; and shear-to-moment interaction at the FRP plate end [Smith and Teng 2003; Teng and Yao 2007; Yao and Teng 2007, Raoof and Hassanen 2000; Zhang 2011; Zhang and Teng 2014; Rahimi and Hutchinson 2001; Benjeddou et al. 2007]. The latter parameter can be also expressed in terms of the distance between the FRP plate end and the beam support.

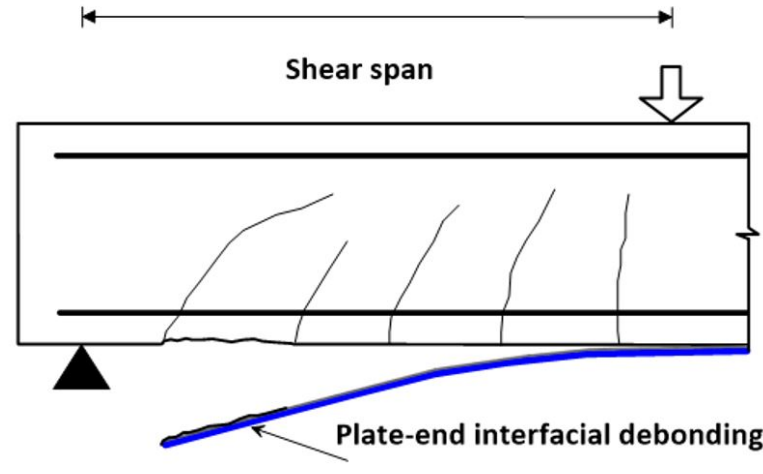

(a) Schematic representation of PE interfacial debonding.

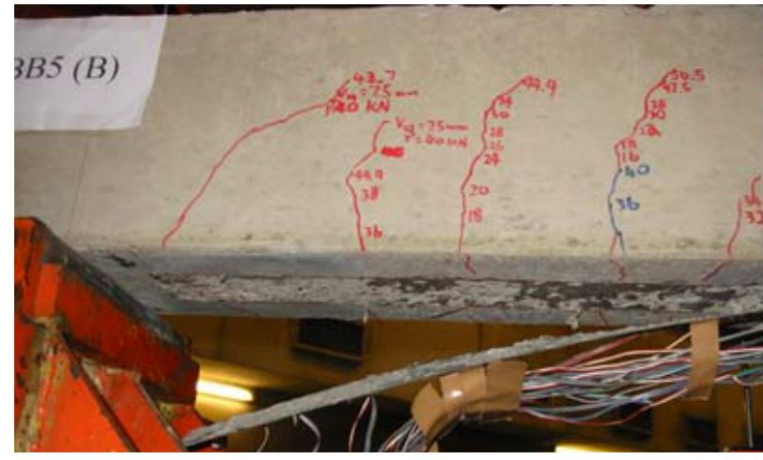

(b) PE interfacial debonding, adopted from [Teng and Chen 2007].

Figure 3. Plate-end interfacial debonding in FRP-strengthened RC beams.

Several studies have been carried out over the years to investigate the plate end debonding of reinforced concrete beams strengthened in flexure using external FRP reinforcement. Pham and Al-Mahaidi (2006) tested FRP-strengthened beams to investigate their failure mechanisms. The test variables were the CFRP bond length, area of tension steel, and the number of CFRP layers. The main failure mode observed was CCS, and the enhancement in ultimate capacity due to FRP-strengthening was reduced with decreased bond length of CFRP in the shear span. On the other hand, increasing the 
number of tension steel bars and CFRP layers caused a limited increase in the ultimate capacity due to FRP-strengthening with no change in the PE debonding failure mode.

The effect of FRP plate length within the shear span in strengthened beams is an important parameter that may lead to the premature failure by PE debonding. Nguyen et al. (2001) studied the effect of FRP plate length on the performance of strengthened RC beams. It was observed that the ultimate load of the strengthened beams with CFRP plates shorter than the span length was much lower than the theoretical flexural capacity of the strengthened section, indicating a loss of composite action prior to failure. In another study conducted by Fanning and Kelly (2001), the effectiveness of FRP-strengthening was significantly reduced when the CFRP plate lengths were shortened as the failure mode shifted from IC debonding to CCS. Similarly, Sebastian (2001) investigated the difference between the mechanisms of PE debonding and IC debonding failures. It was concluded that the curtailment of the FRP plates far from the support increased the likelihood of PE debonding failure. Brena et al. (2003) investigated the effect of various bond lengths of FRP in the shear span on the specimen's behavior. In their study, the CFRP plates debonded from the surface of the concrete for all the test specimens, even when the composites covered nearly the entire length of the shear span. The results indicated that relying on the contact length between the FRP composites and the concrete surface is not sufficient to eliminate PE debonding. Smith and Teng (2003) have also investigated the effect of the plate end distance of FRP away from the support on the debonding failure load. All strengthened beams in their study failed by debonding at the plate end. For each beam, an increase in the plate end distance led to a decrease in the debonding failure load. This showed that there is a significant interaction between bending and shear at the FRP plate end. Al-Tamimi et al. (2011) studied the effect of different CFRP plate length/shear span ratios (0, 25, 70, and 85\%) on the flexural behavior of strengthened RC beams. A reduction in the debonding failure load was observed as the CFRP plate length decreased, but all the strengthened beams failed in a brittle manner by PE debonding.

The width of EB FRP is another important parameter that may control the failure mechanism and hence the type of debonding failure (PE or IC debonding failure). In the study conducted by Benjeddou et al. (2007), a change in the failure mode from CCS to PE interfacial debonding was observed in one of the strengthened beams when the width of the FRP laminated was decreased from 100 to $50 \mathrm{~mm}$. Also, a shift of the failure mode from IC debonding to CCS failure was reported in the study conducted by Al-Saawani et al. (2015) when the width of CFRP plates was increased from 240 to $360 \mathrm{~mm}$. Considerable reduction in the utilization of the CFRP material resulted from such shift of the failure mode.

The thickness of EB FRP plate is a design parameter that may also control the type of PE debonding failure. Test results in the study conducted by Maalej and Bian (2001) have shown that the thickness of EB CFRP affects the shear stress concentration at the CFRP/concrete interface and the beam failure mode. The study revealed a shift in the failure mode from CFRP rupture at the middle of a beam strengthened by one layer of $0.11 \mathrm{~mm}$ thick CFRP sheet to the failure by CCS for the other beams strengthened by more than one layer of CFRP. In another study conducted by Gao et al. (2004b), the test results have shown that increasing the CFRP strip thickness from 0.22 to $0.44 \mathrm{~mm}$ has resulted in a transition in the failure mechanism from PE interfacial debonding along the CFRP-concrete interface to CCS. Generally, it is noted from experimental results reported in the literature that when concrete cover separation is the dominant failure mode, the effect of FRP thickness is not consistent. With the increase of FRP thickness, the load capacity of FRP-strengthened beams could decrease [Maalej and Bian 2001], remain almost the same [Ahmed and Van Gemert 1999; Gao et al. 2004a], or increase significantly [Pham and Al-Mahaidi 2006; Beber et al. 1999; David et al. 1999].

The effect of shear-span/depth ratio on the ultimate capacities and failure modes of FRP-strengthened beams was experimentally investigated by Garden et al. (1998). Four-point bending tests were carried out on beams of $1.0 \mathrm{~m}$ long having shear-span/depth ratios of 3.0, 3.4, and 4.0. These specimens failed by CCS. The test results have shown an increase in the ultimate moment in the beams with increased shear-span/depth ratio. However, such beams have failed at almost the same shear load.

The amount of shear reinforcement in a strengthened RC beam may influence the FRP PE debonding failure. With higher amount of shear reinforcement, a more control on the shear cracking is achieved. Limited studies exist to examine the influence of the amount of shear reinforcement in a strengthened beam on its debonding failure. Buyukozturk et al. (2002) have investigated the effect of increasing the amount of shear reinforcement on the load carrying capacity and failure mode of CFRP-strengthened beams. In their study, two strengthened beams (with different amounts of shear reinforcement) have failed by PE debonding; however, the failure load of the strengthened beam that had higher amount of shear reinforcement was approximately $15 \%$ higher than that of the other strengthened beam with the lesser amount of shear reinforcement.

Hasnat (2014) has investigated the effect of different thicknesses of clear cover of concrete $(12.5 \mathrm{~mm}, 25.0 \mathrm{~mm}$ and $37.5 \mathrm{~mm}$ ) while maintaining the same effective depth of the beams to understand the behavior of substrate stress of 
concrete in FRP-strengthened RC beams. In all cases the test beams failed by CCS, and the enhancement in the moment capacity was found larger in the strengthened beams having smaller clear cover compared to beams with larger clear cover.

\section{PREDICTION MODELS OF PLATE END DEBONDING FAILURE}

Proper design of FRP-strengthened RC members against different failure modes is a key issue of this technique. The risk of failure by IC or PE debonding should be considered in design in order to determine the load carrying capacity of the FRP-strengthened member. Several codes and guidelines for the application of FRP in construction have been developed [ACI 440.2, 2017; International Federation for Structural Concrete, 2001; GB-50608, 2010; Concrete Society 2012; CNR, 2013]. Theoretical formulations have been proposed by researchers and design codes to predict the maximum force/stress in the FRP plates when PE debonding occurs. In many prediction models, PE interfacial debonding is not differentiated from CCS failure.

Strength models for the prediction of CCS failure were developed based on certain assumptions of its failure mechanisms. In some research studies, CCS is thought to be triggered by the development of shear cracks at the plate end region. As a result, shear capacity-based models have been proposed [Teng and Yao 2007; Smith and Teng 2002b; Oehlers 1992; Jansze 1997; Ahmed and Van Gemert 1999]. In such models, the failure load associated to CCS is generally determined to be in the range between the shear strength of concrete in the unstrengthened beam and the full shear strength of the FRP-strengthened beam. In other studies, the so-called concrete tooth models were proposed based on experimental observations in which the concrete cover between the major crack near the FRP plate end and its adjacent major crack behaves like a tooth, which can be treated as a cantilever beam. It is suggested in these studies that CCS occurs when the combination of normal and shear stresses at the root of the 'tooth' exceed the tensile strength of concrete [Raoof and Hassanen 2000; Raoof and Zhang 1997; Pimanmas and Pornpongsaroj 2004]. An early classification of PE prediction models was used by Smith and Teng (2002a), in which the models were grouped into: shear capacity based models, concrete tooth models, and interfacial stress based models. A review of selected PE debonding models is presented in Table 1, which includes models provided by international codes and guidelines (International Federation for Structural Concrete, 2001), Concrete Society (2012), and Italian code (2013)) and models proposed by researchers such as Jansze (1997), Chen and Teng (2001), Smith and Teng (2002b), Colotti et al. (2004), and Teng and Yao (2007).

\section{EVALUATION OF PE DEBONDING MODELS}

A review of existing models for predicting PE debonding failure in FRP-strengthened RC beams was presented in Table 1. In this part, the accuracy of these models is examined by comparing their predictions with test results available in the literature. For this purpose, a database of 158 beam tests was established as part of this study. The database was

Table 1. Models for prediction of plate-end debonding.

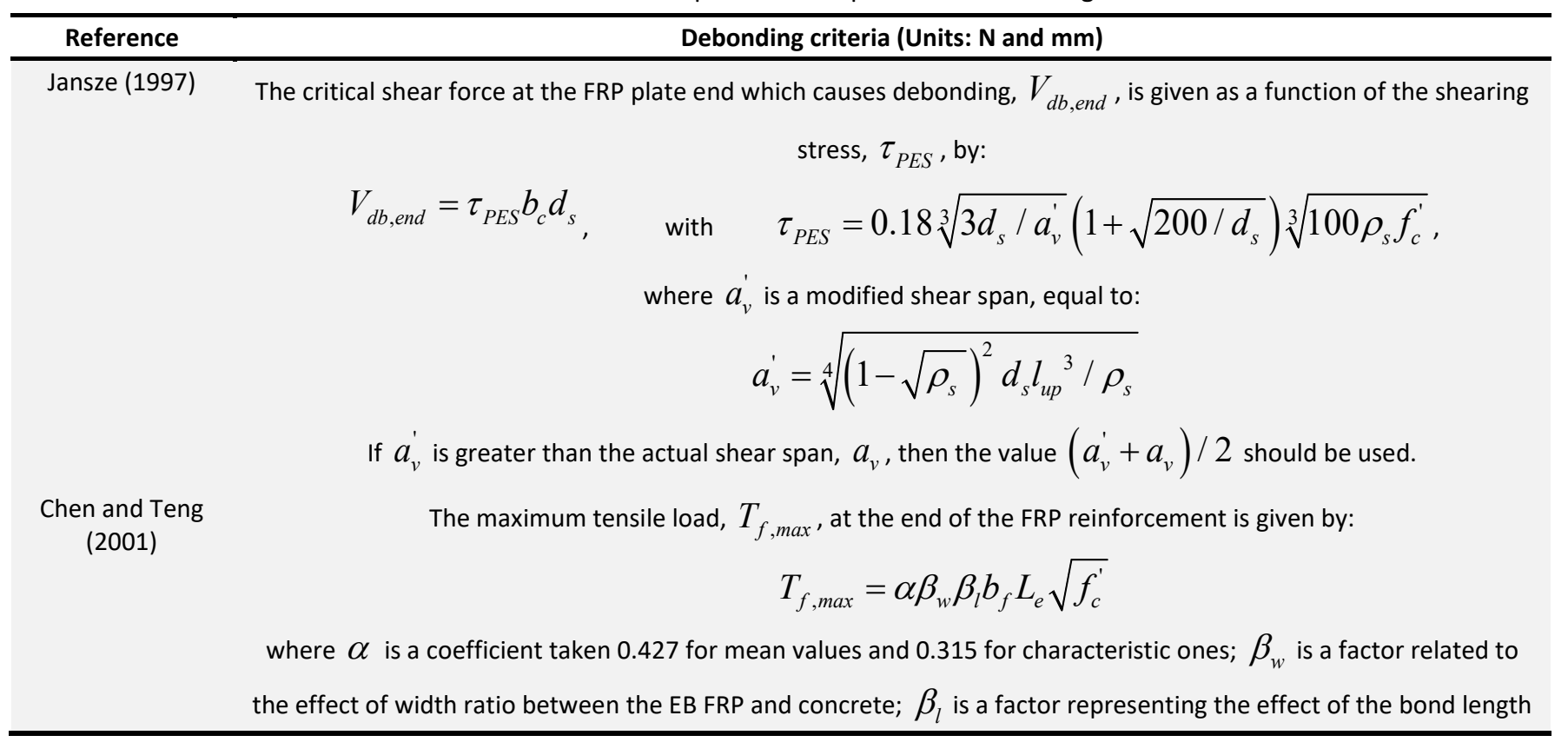


Table 1. Continued...

\section{Reference}

(2002b)

Colotti et al. (2004)

Teng and Yao (2007)

\section{Debonding criteria (Units: $\mathbf{N}$ and $\mathrm{mm}$ )}

of the EB FRP; $L_{e}$ is the effective bond length. The previous factors could be determined by the following equations:

$$
\beta_{w}=\sqrt{\frac{2-b_{f} / b_{c}}{1+b_{f} / b_{c}}}, \beta_{l}=\sin \left(\pi L / 2 L_{e}\right) \text { in case }<L_{e}=\sqrt{E_{f} t_{f} / \sqrt{f_{c}^{\prime}}} .
$$

The debonding shear force at the plate end, $V_{d b, \text { end }}$, is given by:

$$
V_{d b, \text { end }}=\eta V_{c}
$$

where $V_{c}$ is the shear capacity of the concrete beam alone without the contribution from the shear reinforcement; and $\eta$ is taken equal to 1.5 .

The ultimate shear load for the plate-end failure mode of FRP-strengthened beam is:

$$
\begin{aligned}
& \text { with } \\
& U_{y}=\left\{\begin{array}{lr}
b_{m}\left[2.77+0.06\left(f_{c}^{\prime}-20\right)\right] & \text { for PE debonding } \\
\operatorname{Min}\left\{b_{m}\left[2.77+0.06\left(f_{c}^{\prime}-20\right)\right],\left(f_{c t} s_{c} b_{c} / C_{c}\right)\right\} & \text { for CCS }
\end{array}\right.
\end{aligned}
$$$$
V_{d b, \text { end }}=p_{y} d_{s}\left[\phi+\alpha-\sqrt{(\phi+\alpha)^{2}-2 \phi \beta}\right], p_{y}>0
$$$$
p_{y}=A_{v} f_{y v} / s_{v} ; \quad \alpha=a_{v} / d_{s} ; \quad \beta=l_{a} / d_{s} ; \quad \phi=U_{y} / p_{y}
$$

where $b_{m}=\left(b_{c}+b_{f}\right) / 2 ; s_{c}$ is the width of the tie element, suggested by Colotti et al. (2004) equal to:

$s_{c}=l_{c} / 5$, in which the crack spacing, $l_{c}$, could be calculated according to Eurocode2 by:

$l_{c}=50+0.25 k_{1} k_{2} \phi_{s} / \rho_{r}$, where $k_{1}$ and $k_{2}$ are 0.8 and 0.5 , respectively; and $\rho_{r}=A_{s e} / 2.5 b c_{c}$, in which

$$
A_{\text {se }}=A_{s} / 2 \text {. }
$$

The flexural debonding moment of FRP plate end located in a pure bending region is:

$$
M_{d b, f}=0.488 M_{u, o} /\left(\alpha_{\text {flex }} \alpha_{\text {axial }} \alpha_{w}\right)^{1 / 9} \leq M_{u, o} \text {, }
$$

where $\alpha_{\text {flex }}, \alpha_{\text {axial }}$ and $\alpha_{w}$ are parameters defined by:

$$
\alpha_{f l e x}=(E I)_{f, c}-(E I)_{o, c} /(E I)_{o, c}, \quad \quad \alpha_{\text {axial }}=E_{f} t_{f} / E_{c} d_{s}, \quad \alpha_{w}=b_{c} / b_{f} \leq 3,
$$

where $(E I)_{f, c}$ and $(E I)_{o, c}$ are the flexural rigidities of the cracked section with and without EB FRP,

respectively and $M_{u, 0}$ is the theoretical ultimate moment of the un-plated section, which is also the upper bound

$$
\text { of the flexural debonding moment } M_{d b, f} \text {. }
$$

The debonding shear force at an FRP plate end located in a region of (nearly) zero moment is:

$$
V_{d b, s}=V_{c}+V_{f}+\varepsilon_{v, e} \overline{V_{s}},
$$

where $\bar{V}$ is the shear force carried by the shear steel reinforcement per unit strain, given by:

$$
\overline{V_{s}}=A_{s v} E_{s v} d_{e} / s_{v},
$$

The effective strain in the shear steel reinforcement, $\varepsilon_{v, e}$, is given by (in $\mu \varepsilon$ ):

$$
\varepsilon_{v, e}=10 /\left(\alpha_{f l e x} \alpha_{E} \alpha_{t} \alpha_{w}\right)^{1 / 2}, \quad \text { with } \quad \alpha_{E}=E_{f} / E_{c} ; \alpha_{t}=\left(t_{f} / d_{s}\right)^{1.3} \text {, }
$$


Table 1. Continued...

Reference (International Federation for Structural Concrete, 2001)

Concrete Society (2012) TR55

CNR DT200

(CNR, 2013)

\section{Debonding criteria (Units: $\mathrm{N}$ and $\mathrm{mm}$ )}

For the predictions of the shear capacity contributed by the concrete and FRP plate $\left(V_{c}+V_{f}\right)$, The authors proposed that Oehlers et al.'s $(2004,2005)$ prestress model be adopted.

An interaction between plate-end shear and bending was proposed as follows:

$$
\left(M_{d b, \text { end }} / 0.85 M_{d b, f}\right)^{2}+\left(V_{d b, \text { end }} / 0.85 V_{d b, s}\right)^{2}=1.0
$$

$$
\varepsilon_{f d}=\left\{\begin{array}{cc}
c_{1} k_{c} k_{b} \sqrt{f_{c t} / n_{f} E_{f} t_{f}} & , l_{b} l_{b, \text { max }} \\
c_{1} k_{c} k_{b} \sqrt{f_{c t} / n_{f} E_{f} t_{f}} \cdot\left(l_{b} / l_{b, \max }\right)\left(2-l_{b} / l_{b, \max }\right), & l_{b}<l_{b, \max }
\end{array}\right.
$$

where the maximum anchorage length, $l_{b, \max }=\sqrt{\left(n E_{f} t_{f}\right) /\left(c_{2} f_{c t}\right)} ;=1$ for beams with sufficient internal and external shear reinforcement and for slabs, otherwise $=0.9 ; c_{1}$ and $c_{2}$ can be taken 0.64 and 2.0, respectively for CFRP strips; $k_{c}=1$, but for concrete with low compaction, $k_{c}=0.67$; and $k_{b}$ is a geometry

$$
\text { factor, given by: }
$$

$$
\varepsilon_{f d}=\left\{\begin{array}{rr}
0.5 k_{b} \sqrt{f_{c t} / n E_{f} t_{f}} & \quad l_{b} l_{b, \max } \\
0.5 k_{b} \sqrt{f_{c t} / n E_{f} t_{f}} \cdot l_{b} / l_{b, \max }\left(2-l_{b} / l_{b, \max }\right) & , l_{b}<l_{b, \max }
\end{array}\right.
$$

where $k_{b}$ is a geometry factor given by:

$$
k_{b}=1.06 \sqrt{\left(2-b_{f} / b_{c}\right) /\left(1+b_{f} / 400\right)} \geq 1 \text {, with } \quad b_{f} / b_{c} \geq 0.33
$$

The maximum anchorage length, $l_{b, \max }$, is given by: $l_{b, \max }=0.7 \sqrt{n_{f} E_{f} t_{f} / f_{c t}}$

$$
\varepsilon_{f d}=\left\{\begin{array}{lr}
1 / \gamma_{f, d} \sqrt{2 \Gamma_{F d} / n_{f} E_{f} t_{f}} & , l_{b} l_{b, \text { max }} \\
1 / \gamma_{f, d} \sqrt{2 \Gamma_{F d} / n_{f} E_{f} t_{f}} \cdot\left(l_{b} / l_{b, \text { max }}\right)\left(2-l_{b} / l_{b, \max }\right) & , l_{b}<l_{b, \text { max }}
\end{array}\right.
$$

where $\gamma_{f d}$ is a partial factor (1.2-1.5); $\Gamma_{F d}$ is the design value of the specific fracture energy of the FRP-concrete interface, given by:

$$
\Gamma_{F d}=k_{b} k_{G} \sqrt{f_{c}^{\prime} f_{c t}}
$$

in which $k_{G}$ is a corrective factor taken for pre-cured FRP $0.063 \mathrm{~mm}$ for the mean value and $0.023 \mathrm{~mm}$ for the $5 \%$ fractile value) and for wet lay-up FRP ( $0.077 \mathrm{~mm}$ for the mean value and $0.037 \mathrm{~mm}$ for the $5 \%$ fractile value); $k_{b}$ is a

$$
\begin{gathered}
k_{b}=\left\{\begin{array}{r}
\text { geometric coefficient given by: } \\
\sqrt{\left(2-b_{f} / b_{c}\right) /\left(1+b_{f} / b_{c}\right)} \geq 1, \quad b_{f} / b_{c} \geq 0.25 \\
1.18, b_{f} / b_{c}<0.25
\end{array}\right. \\
\text { The effective bond length, } L_{e}, \text { is calculated by: } \\
L_{e}=\min \left\{\left(1 / \gamma_{R d} f_{b d}\right) \sqrt{\pi^{2} E_{f} t_{f} \Gamma_{F d} / 2}, 200 \mathrm{~mm}\right\} \\
\text { where } f_{b d}=2 \Gamma_{F d} / S_{u, \text { with }} S_{u}=0.25 \mathrm{~mm} \text {, and } \gamma_{R d}=1.25 \text { as a corrective factor. }
\end{gathered}
$$

assembled from 37 studies as given in Table 2. These studies were reported in the technical literature on simply supported RC beams externally strengthened with FRP sheets/plates that were terminated at various locations from the support. The included beams in this database met the following requirements: (1) failure of the beam was by PE interfacial debonding or CCS; (2) the FRP plate was neither prestressed nor anchored at its ends; and (3) sufficient details 
for various geometric and material parameters were provided. Table 2 lists the acronyms for the beams included in the database and the corresponding references in order to avoid making the paper lengthy. The database had a broad range of design parameters. Considering the beam geometry, the width of the test beams was in the range of 100 to $400 \mathrm{~mm}$ with a total beam height of 100 to $450 \mathrm{~mm}$, while the clear span ranged from 812 to $3800 \mathrm{~mm}$. The test beams had different shear span/depth ratio in the range of 2.3 to 6.3. The tension steel reinforcement ratio ranged from 0.32 to $4.36 \%$. Considering the material type, the database included 59 beams strengthened by pultruded FRP plates and 99 beams strengthened by wet lay-up FRP sheets. The width of the EB FRP was in the range 30 to $360 \mathrm{~mm}$. The thickness of dry fibers was in the range of 0.165 to $1.584 \mathrm{~mm}$ for the wet lay-up FRP sheets while the total thickness for pultruded FRP was in the range of 0.5 to $4.763 \mathrm{~mm}$. The elastic modulus of the FRP materials ranged between 10.3 and $300 \mathrm{GPa}$. The beams were cast with concrete of a compressive strength in the range of 9.9 to $66.4 \mathrm{MPa}$. The loading configurations for these test specimens consisted of four-point bending ( 144 test beams) and three-point bending (14 test beams).

A comparison was conducted between the ultimate experimental load at PE debonding failure, $P_{u, \exp }$, and the calculated values, $P_{u, c a l}$, using the different prediction models, as shown in Table 2. In addition, the ratio of $P_{u, e x p} / P_{u, c a l}$ is obtained, and the average value, standard deviation, and the coefficient of variation (CoV) of this ratio are calculated for each prediction model and given in Table 2. The number of the test beams with the ratio $P_{u, \text { exp }} / P_{u, c a l}$ being below 1.0 (i.e., number of unsafe predictions) is also given in the same table. In addition, the correlation between experimental and predicted values of the ultimate load at PE debonding is plotted and shown in Figures 4-11 for each prediction model. From these comparisons, the following can be concluded:

- The critical shear forces at the plate end that cause debonding proposed by Jansze's model (1997) are compared with the test results in Table 2 and Figure 4. It is noted that this prediction model is invalid for FRP plates that are extended all the way to the support because the value of the modified shear span, $a_{v}^{\prime}$, becomes zero and the equation of $V_{d b \text {,end }}$ in Table 1 predicts that debonding will not occur. Generally, the predictions of the ultimate debonding load from this model are conservative for most of the test beams in the database (72.8\%), with an average value for $P_{u, \text { exp }} / P_{u, c a l}$ of 1.30 and a coefficient of variation of $33.8 \%$.

- Comparisons of the ultimate debonding loads proposed by Chen and Teng's model (2001) are shown in Table 2 and Figure 5. The predictions from this model are highly conservative for almost all the test results (97.5\%), with an average value for $P_{u, \exp } / P_{u, c a l}$ of 1.48 and a coefficient of variation of $22.8 \%$.

- Smith and Teng's (2002b) prediction model is simple because it only uses a multiple of the shear capacity of the concrete beam alone which is suggested to be calculated using the Australian code for concrete structures AS 3600 (1988). The shear debonding forces obtained from this model are compared with the test results in Table 2 and Figure 6. This formulation provides conservative predictions for the ultimate load at PE debonding for $89.2 \%$ of the test beams in the database, with an average value for $P_{u, \text { exp }} / P_{u, c a l}$ of 1.44 and a coefficient of variation of $26.1 \%$.

- The predictions of Colotti et al.'s model (2004) are compared with the test results in Table 2 and Figure 7. The model provided on average close predictions to the experimental results but with a high scatter, with an average value for $P_{u, \exp } / P_{u, c a l}$ of 1.06 and a coefficient of variation of 31.6\%. However, this model provides unsafe predictions for the ultimate load at PE debonding for a $44.9 \%$ of the test beams.

- A comparison of the test results with the predictions of Teng and Yao's model (2007) is shown in Table 2 and Figure 8. In this model, the shear capacity of the beam $\left(V_{c}+V_{f}\right)$ was determined using Oehlers et al.'s model $(2004,2005)$ which considers the contribution of the concrete as well as the FRP plates to the shear capacity of the strengthened beam. This model provides less conservative and scattered predictions with an average value for $P_{u, \exp } / P_{u, c a l}$ of 1.18 and a CoV of $23.9 \%$. Unsafe predictions of the ultimate debonding load were observed for $29.1 \%$ of the test results.

- The predictions provided by the fib bulletin 14 model (International Federation for Structural Concrete, 2001) are close to the test results with less scatter level as shown in Table 2 and Figure 9. The average value for $P_{u, e x p} / P_{u, c a l}$ is 1.19 and the coefficient of variation is $19.9 \%$. However, the predictions of this method were unsafe for $21.5 \%$ of the test results. 
- $\quad$ The predictions of the Concrete Society Technical Report 55 model (2012) are compared with the test results in Table 2 and Figure 10. These predictions are found to be conservative and scattered, with an average value for $P_{u, \text { exp }} / P_{u, c a l}$ of 1.37 and a coefficient of variation of $20.8 \%$. Predictions of this method are found to be unsafe for only $7 \%$ of the test results.

- Comparisons of the test results with the predictions given by the Italian code CNR-DT 200 (CNR, 2013) are shown in Table 2 and Figure 11. This model provided reasonable levels of conservatism and scatter, with an average value for $P_{u, \exp } / P_{u, c a l}$ of 1.16 and a coefficient of variation of $19.7 \%$.

Generally, this assessment of the PE debonding models using the experimental database reveals the discrepancies among these models in predicting the load carrying capacities of the beams. Although Colotti et al.'s model (2004) provided the closest predictions to the experimental data considering the average ratio of $P_{u, \exp } / P_{u, c a l}$, the predictions were scatter with a significant number in the unsafe side. More reasonable predictions were obtained from the fib bulletin 14 (International Federation for Structural Concrete, 2001), the Italian code CNR-DT 200 (CNR, 2013), and Teng and Yao (2007) model.

\section{CODE PROVISIONS TO AVOID PE DEBONDING}

Plate-end debonding is a brittle mode of failure which occurs suddenly. Therefore, some of the design codes provide specific precautions and guidelines to avoid such failure mode. These precautions and guidelines can be categorized under two main approaches as presented in the following subsections.

\subsection{Approach related to the cut-off point of EB FRP}

The $\mathrm{ACl} 440.2$ ( $\mathrm{ACl}$ Committee 440, 2017) guide does not determine the governing failure mode that controls the contribution of FRP reinforcement to the strengthened members. In general, $\mathrm{ACl} 440.2(\mathrm{ACl} \mathrm{Committee} \mathrm{440,2017)}$ indicates that the FRP end peeling failure can be mitigated by minimizing the stress at the FRP curtailment by locating the curtailment as close to the region of zero moment as possible, by using an end anchorage, or by both. However, it was observed in several studies [Brena et al. 2003; Al-Saawani et al. 2015; Hasnat et al. 2016; Aprile and Feo 2007] that PE debonding was not prevented by relying solely on extending the FRP plate close to the supports. This is because although the bending moment is almost zero close to the support in simply supported beams, shear cracks are developed in this zone. Widening of the shear cracks increases the interfacial shear stresses as well as the normal stresses at the plate end region leading to CCS.

Another procedure was also prescribed by the $\mathrm{ACl} 440.2$ guide ( $\mathrm{ACl}$ Committee 440, 2017) in order to avoid FRP end peeling failure, which is related to the location of the cutoff points of the FRP laminate. For simply supported beams, a single-ply FRP 
Table 2. Database of beams failed by plate-end debonding (comparison between testes and prediction models).

\begin{tabular}{|c|c|c|c|c|c|c|c|c|c|c|c|}
\hline \multirow[b]{2}{*}{ Reference } & \multirow[b]{2}{*}{ Beam } & \multicolumn{2}{|c|}{ Exp. Results } & \multicolumn{8}{|c|}{ Comparison results, $P_{u, e x p} / P_{u, c a l}$} \\
\hline & & $\begin{array}{l}P_{u, e x p} \\
(k N)\end{array}$ & $\begin{array}{l}\text { Failure } \\
\text { modet }\end{array}$ & $\begin{array}{l}\text { Jansze } \\
\text { (1997) }\end{array}$ & $\begin{array}{c}\text { Chen \& } \\
\text { Teng } \\
\text { (2001) }\end{array}$ & $\begin{array}{c}\text { Smith \& } \\
\text { Teng } \\
\text { (2002b)* }\end{array}$ & $\begin{array}{l}\text { Colotti et al. } \\
\text { (2004) }\end{array}$ & $\begin{array}{c}\text { Teng \& } \\
\text { Yao } \\
(2007) \ddagger\end{array}$ & $\begin{array}{c}\text { fib bulletin } \\
14 \\
\text { (International } \\
\text { Federation for } \\
\text { Structural } \\
\text { Concrete, 2001) }\end{array}$ & $\begin{array}{l}\text { CS TR55 } \\
\text { (Concrete } \\
\text { Society, } \\
\text { 2012) }\end{array}$ & $\begin{array}{l}\text { CNR- } \\
\text { DT200 } \\
\text { (CNR, } \\
\text { 2013) }\end{array}$ \\
\hline \multirow{5}{*}{$\begin{array}{l}\text { Ritchie et al. } \\
\text { (1991) }\end{array}$} & $\mathrm{C}$ & 110.8 & CCS & 0.63 & 1.54 & 1.18 & 1.02 & 0.84 & 1.35 & 1.46 & 1.33 \\
\hline & $\mathrm{D}$ & 119.3 & CCS & 0.67 & 1.66 & 1.27 & 1.11 & 0.90 & 1.46 & 1.57 & 1.43 \\
\hline & G & 125.8 & CCS & 0.41 & 1.78 & 1.31 & 1.16 & 0.84 & 1.58 & 1.69 & 1.55 \\
\hline & 1 & 101.2 & CCS & 0.57 & 1.38 & 1.08 & 0.71 & 0.88 & 1.10 & 1.20 & 1.07 \\
\hline & M & 144.1 & CCS & 0.47 & 2.00 & 1.50 & 0.80 & 1.22 & 1.45 & 1.64 & 1.40 \\
\hline \multirow{4}{*}{$\begin{array}{l}\text { Quantrill et a } \\
\text { I. (1996a) }\end{array}$} & B2 & 34.0 & CCS & 0.88 & 1.30 & 1.32 & 1.04 & 1.01 & 1.11 & 1.24 & 1.11 \\
\hline & B3 & 24.6 & CCS & 0.64 & 1.15 & 0.95 & 0.90 & 0.75 & 1.07 & 1.15 & 1.12 \\
\hline & B4 & 35.0 & CCS & 0.91 & 1.34 & 1.36 & 1.14 & 1.06 & 1.17 & 1.30 & 1.22 \\
\hline & B6 & 40.8 & CCS & 1.06 & 1.29 & 1.58 & 1.25 & 1.19 & 1.06 & 1.21 & 1.06 \\
\hline \multirow{2}{*}{$\begin{array}{l}\text { Quantrill et a } \\
\text { I. (1996b) }\end{array}$} & $\mathrm{A} 1 \mathrm{C}$ & 44.0 & PED & 1.04 & 1.61 & 1.55 & 2.00 & 1.19 & 1.36 & 1.52 & 1.34 \\
\hline & $\mathrm{A} 2 \mathrm{C}$ & 37.4 & PED & 1.05 & 1.50 & 1.57 & 1.85 & 1.26 & 1.28 & 1.42 & 1.29 \\
\hline \multirow{3}{*}{$\begin{array}{l}\text { Arduini et al. } \\
\text { (1997) }\end{array}$} & A4 & 110.0 & CCS & 1.39 & 1.56 & 1.26 & 1.06 & 1.35 & 1.21 & 1.50 & 1.17 \\
\hline & A5 & 90.0 & CCS & 1.14 & 1.24 & 1.03 & 0.86 & 1.08 & 0.95 & 1.19 & 0.92 \\
\hline & B3 & 228.0 & CCS & 1.20 & 1.65 & 1.20 & 0.71 & 1.07 & 1.20 & 1.36 & 1.11 \\
\hline \multirow{9}{*}{$\begin{array}{l}\text { Garden et al. } \\
\quad(1997)\end{array}$} & $1 \mathrm{Au}$ & 39.6 & CCS & 0.99 & 1.48 & 1.48 & 1.15 & 1.10 & 1.24 & 1.39 & 1.14 \\
\hline & $2 A u$ & 38.6 & CCS & 0.97 & 1.63 & 1.44 & 1.13 & 1.12 & 1.37 & 1.54 & 1.26 \\
\hline & $3 A u$ & 39.0 & $\mathrm{CCS}$ & 0.98 & 1.94 & 1.46 & 1.28 & 1.19 & 1.63 & 1.83 & 1.50 \\
\hline & $1 \mathrm{Bu}$ & 36.6 & CCS & 0.92 & 1.36 & 1.37 & 1.14 & 1.04 & 1.17 & 1.30 & 1.14 \\
\hline & $2 \mathrm{Bu}$ & 34.0 & CCS & 0.85 & 1.43 & 1.27 & 0.99 & 1.00 & 1.23 & 1.37 & 1.20 \\
\hline & $3 \mathrm{Bu}$ & 34.6 & CCS & 0.87 & 1.71 & 1.29 & 1.13 & 1.08 & 1.47 & 1.64 & 1.44 \\
\hline & $1 \mathrm{Cu}$ & 32.0 & CCS & 0.80 & 1.21 & 1.20 & 1.06 & 0.93 & 1.07 & 1.18 & 1.08 \\
\hline & $2 \mathrm{Cu}$ & 35.6 & CCS & 0.89 & 1.53 & 1.33 & 1.11 & 1.07 & 1.35 & 1.49 & 1.36 \\
\hline & $3 \mathrm{Cu}$ & 30.8 & $\mathrm{CCS}$ & 0.77 & 1.56 & 1.15 & 1.01 & 0.98 & 1.37 & 1.52 & 1.39 \\
\hline \multirow{4}{*}{$\begin{array}{l}\text { Garden et al. } \\
\text { (1998) }\end{array}$} & B1u, 1.0 & 36.5 & CCS & 0.82 & 1.16 & 1.23 & 1.02 & 0.95 & 0.99 & 1.11 & 1.02 \\
\hline & B3u, 1.0 & 34.0 & CCS & 0.88 & 1.40 & 1.31 & 1.01 & 1.05 & 1.19 & 1.34 & 1.22 \\
\hline & B4u, 1.0 & 34.5 & CCS & 0.89 & 1.67 & 1.33 & 0.94 & 1.12 & 1.42 & 1.60 & 1.46 \\
\hline & B1u, 2.3 & 100.3 & CCS & 1.10 & 1.54 & 1.39 & 0.96 & 1.44 & 1.26 & 1.42 & 1.27 \\
\hline \multirow{6}{*}{$\begin{array}{l}\text { Beber et al. } \\
\text { (1999) }\end{array}$} & VR5 & 102.2 & CCS & 1.65 & 2.14 & 1.74 & 0.83 & 1.48 & 1.46 & 1.76 & 1.38 \\
\hline & VR6 & 100.6 & CCS & 1.63 & 2.11 & 1.71 & 0.82 & 1.46 & 1.44 & 1.73 & 1.36 \\
\hline & VR7 & 124.2 & CCS & 2.01 & 2.71 & 2.11 & 0.96 & 1.91 & 1.78 & 2.23 & 1.56 \\
\hline & VR8 & 124.0 & CCS & 2.00 & 2.71 & 2.11 & 0.96 & 1.90 & 1.78 & 2.22 & 1.56 \\
\hline & VR9 & 129.6 & CCS & 2.09 & 2.80 & 2.20 & 1.00 & 2.00 & 1.83 & 2.29 & 1.60 \\
\hline & VR10 & 137.0 & CCS & 2.21 & 2.96 & 2.33 & 1.06 & 2.12 & 1.94 & 2.42 & 1.70 \\
\hline \multirow{4}{*}{$\begin{array}{l}\text { David et al. } \\
\text { (1999) }\end{array}$} & P2 & 136.0 & CCS & 1.57 & 1.59 & 1.35 & 1.06 & 1.44 & 1.22 & 1.50 & 1.23 \\
\hline & P3 & 142.2 & CCS & 1.65 & 1.67 & 1.41 & 1.10 & 1.50 & 1.28 & 1.56 & 1.29 \\
\hline & P4 & 156.0 & CCS & 1.80 & 1.99 & 1.55 & 1.21 & 1.69 & 1.48 & 1.86 & 1.52 \\
\hline & P5 & 159.0 & CCS & 1.84 & 2.03 & 1.58 & 1.23 & 1.73 & 1.51 & 1.90 & 1.55 \\
\hline \multirow[t]{5}{*}{ Hau (1999) } & 2 & 106.0 & CCS & 1.83 & 1.21 & 1.57 & 1.09 & 1.37 & 0.92 & 1.14 & 0.90 \\
\hline & 4 & 130.8 & PED & 2.25 & 1.56 & 1.92 & 1.25 & 1.05 & 1.40 & 1.49 & 1.34 \\
\hline & 5 & 158.8 & PED & 1.96 & 1.74 & 2.24 & 1.12 & 1.13 & 1.51 & 1.63 & 1.42 \\
\hline & 6 & 126.2 & CCS & 2.10 & 1.49 & 1.79 & 1.21 & 0.99 & 1.33 & 1.42 & 1.27 \\
\hline & 7 & 107.8 & CCS & 2.00 & 1.28 & 1.56 & 1.90 & 1.28 & 1.15 & 1.22 & 1.10 \\
\hline
\end{tabular}


Table 2 (cont.). Database of beams failed by plate-end debonding (comparison between testes and prediction models).

\begin{tabular}{|c|c|c|c|c|c|c|c|c|c|c|c|}
\hline \multirow[b]{2}{*}{ Reference } & \multirow[b]{2}{*}{ Beam } & \multicolumn{3}{|c|}{ Exp. Results } & \multicolumn{6}{|c|}{ Comparison results, $P_{u, \text { exp }} / P_{u, c a l}$} & \multirow[b]{2}{*}{$\begin{array}{l}\text { CNR- } \\
\text { DT200 } \\
\text { (CNR, } \\
\text { 2013) }\end{array}$} \\
\hline & & $\begin{array}{l}P_{u, e x p} \\
(k N)\end{array}$ & $\begin{array}{l}\text { Failure } \\
\text { modet }\end{array}$ & $\begin{array}{l}\text { Jansze } \\
\text { (1997) }\end{array}$ & $\begin{array}{c}\text { Chen \& } \\
\text { Teng } \\
\text { (2001) }\end{array}$ & $\begin{array}{c}\text { Smith \& } \\
\text { Teng } \\
\text { (2002b)* }\end{array}$ & $\begin{array}{l}\text { Colotti e } \\
\text { t al. } \\
(2004)\end{array}$ & $\begin{array}{c}\text { Teng \& } \\
\text { Yao } \\
(2007) \neq\end{array}$ & $\begin{array}{c}\text { fib bulletin } \\
14 \\
\text { (International } \\
\text { Federation for } \\
\text { Structural } \\
\text { Concrete, 2001) }\end{array}$ & $\begin{array}{l}\text { CS TR55 } \\
\text { (Concrete } \\
\text { Society, } \\
\text { 2012) }\end{array}$ & \\
\hline \multirow[t]{3}{*}{ Ross et al. (1999) } & $1 \mathrm{~B}$ & 80.1 & PED & 0.35 & 2.17 & 1.04 & 0.97 & 0.71 & 1.70 & 1.95 & 1.52 \\
\hline & $2 B$ & 97.9 & PED & 0.34 & 1.94 & 1.05 & 1.02 & 0.79 & 1.62 & 1.80 & 1.49 \\
\hline & $3 B$ & 109.0 & PED & 0.31 & 1.63 & 1.01 & 0.96 & 0.81 & 1.43 & 1.54 & 1.34 \\
\hline \multirow[t]{6}{*}{ Täljsten (1997) } & SB1 & 142.8 & PED & 1.06 & 1.63 & 0.98 & 0.92 & 0.92 & 1.26 & 1.58 & 1.27 \\
\hline & SB2 & 151.0 & PED & 1.20 & 1.72 & 1.03 & 0.97 & 1.01 & 1.33 & 1.67 & 1.34 \\
\hline & SB3 & 147.8 & PED & 1.30 & 1.68 & 1.01 & 0.95 & 1.08 & 1.30 & 1.64 & 1.31 \\
\hline & MB1 & 159.2 & PED & 1.18 & 1.90 & 1.09 & 1.02 & 1.08 & 1.47 & 1.85 & 1.48 \\
\hline & HB1 & 160.2 & PED & 1.19 & 1.99 & 1.09 & 1.11 & 1.15 & 1.55 & 1.96 & 1.65 \\
\hline & FB1 & 148.8 & PED & 1.10 & 1.75 & 1.02 & 0.86 & 0.98 & 1.33 & 1.68 & 1.24 \\
\hline \multirow{3}{*}{$\begin{array}{l}\text { Tumialan et al. } \\
\text { (1999) }\end{array}$} & A3 & 172.2 & CCS & 0.33 & 1.14 & 1.16 & 1.30 & 0.94 & 1.00 & 1.04 & 0.96 \\
\hline & A8 & 196.4 & CCS & 0.38 & 1.30 & 1.33 & 1.48 & 1.34 & 1.17 & 1.25 & 1.17 \\
\hline & $\mathrm{C} 2$ & 158.6 & CCS & 0.30 & 1.05 & 1.07 & 1.28 & 1.06 & 0.92 & 0.95 & 0.89 \\
\hline \multirow[t]{15}{*}{ Ahmed (2000) } & AF.2 & 83.0 & CCS & 1.89 & 1.39 & 1.59 & 1.13 & 1.41 & 1.23 & 1.34 & 1.22 \\
\hline & AF.2.1 & 85.8 & CCS & 1.87 & 1.43 & 1.64 & 0.99 & 1.29 & 1.27 & 1.38 & 1.26 \\
\hline & AF. 3 & 96.6 & CCS & 1.97 & 1.61 & 1.85 & 0.96 & 1.30 & 1.43 & 1.56 & 1.42 \\
\hline & AF. 4 & 111.0 & CCS & 1.90 & 1.85 & 2.12 & 1.11 & 1.37 & 1.65 & 1.79 & 1.63 \\
\hline & BF.2-1 & 90.0 & PED & 1.54 & 1.50 & 1.72 & 1.03 & 1.23 & 1.34 & 1.45 & 1.32 \\
\hline & BF.3-1 & 104.0 & PED & 1.78 & 1.74 & 1.99 & 1.07 & 1.35 & 1.54 & 1.68 & 1.53 \\
\hline & CF.2-1 & 104.8 & CCS & 1.89 & 1.46 & 1.81 & 1.02 & 1.28 & 1.33 & 1.43 & 1.32 \\
\hline & CF.3-1 & 118.2 & CCS & 1.99 & 1.48 & 1.94 & 1.15 & 1.38 & 1.35 & 1.44 & 1.34 \\
\hline & CF.4-1 & 140.2 & CCS & 2.07 & 1.40 & 2.07 & 1.40 & 1.51 & 1.29 & 1.36 & 1.29 \\
\hline & DF2 & 120.5 & CCS & 1.72 & 1.52 & 1.99 & 1.13 & 1.45 & 1.39 & 1.47 & 1.38 \\
\hline & DF3 & 120.0 & CCS & 1.74 & 1.67 & 2.01 & 1.15 & 1.55 & 1.31 & 1.55 & 1.30 \\
\hline & DF4 & 125.5 & CCS & 1.82 & 1.82 & 2.10 & 1.20 & 1.65 & 1.35 & 1.69 & 1.32 \\
\hline & EF.1-1 & 131.8 & PED & 1.83 & 1.62 & 2.12 & 1.19 & 1.52 & 1.50 & 1.59 & 1.48 \\
\hline & EF.3-1 & 119.0 & PED & 1.76 & 1.55 & 2.04 & 1.17 & 1.50 & 1.39 & 1.47 & 1.38 \\
\hline & EF.4-1 & 120.6 & PED & 1.87 & 1.64 & 2.16 & 1.26 & 1.63 & 1.44 & 1.54 & 1.43 \\
\hline \multirow[t]{6}{*}{ Matthys (2000) } & BF2 & 370.0 & PED & 1.44 & 1.54 & 1.77 & 1.34 & 1.67 & 1.22 & 1.52 & 1.32 \\
\hline & BF3 & 372.0 & PED & 1.47 & 1.57 & 1.81 & 1.37 & 1.71 & 1.24 & 1.55 & 1.35 \\
\hline & BF4 & 368.4 & PED & 1.52 & 1.62 & 1.87 & 1.44 & 1.79 & 1.28 & 1.59 & 1.40 \\
\hline & BF5 & 354.0 & PED & 1.37 & 1.46 & 1.68 & 1.27 & 1.58 & 1.15 & 1.44 & 1.25 \\
\hline & BF8 & 222.6 & PED & 1.14 & 1.55 & 1.31 & 0.91 & 1.11 & 1.20 & 1.52 & 1.31 \\
\hline & BF9 & 191.6 & PED & 1.02 & 1.18 & 1.18 & 1.00 & 0.57 & 1.14 & 1.17 & 1.16 \\
\hline \multirow{4}{*}{$\begin{array}{l}\text { Fanning \& Kelly } \\
\text { (2001) }\end{array}$} & F5 & 100.0 & CCS & 1.24 & 1.45 & 0.91 & 1.09 & 1.21 & 1.09 & 1.34 & 1.06 \\
\hline & F6 & 103.0 & CCS & 1.28 & 1.49 & 0.94 & 1.12 & 1.25 & 1.12 & 1.38 & 1.10 \\
\hline & F7 & 97.5 & CCS & 1.27 & 1.41 & 0.89 & 1.20 & 1.28 & 1.06 & 1.31 & 1.04 \\
\hline & F10 & 82.0 & CCS & 1.09 & 1.19 & 0.75 & 1.19 & 1.17 & 0.89 & 1.10 & 0.87 \\
\hline \multirow[t]{3}{*}{$\begin{array}{l}\text { Maalej \& Bian } \\
\quad \text { (2001) }\end{array}$} & $\begin{array}{c}\text { Beam } \\
3\end{array}$ & 86.0 & CCS & 1.68 & 1.60 & 1.88 & 1.57 & 1.36 & 1.28 & 1.35 & 1.24 \\
\hline & $\begin{array}{c}\text { Beam } \\
4\end{array}$ & 82.0 & CCS & 1.60 & 1.68 & 1.80 & 1.50 & 1.47 & 1.17 & 1.41 & 1.13 \\
\hline & $\begin{array}{l}\text { Beam } \\
5\end{array}$ & 79.0 & CCS & 1.54 & 1.71 & 1.73 & 1.45 & 1.51 & 1.16 & 1.43 & 1.05 \\
\hline
\end{tabular}


Table 2 (cont.). Database of beams failed by plate-end debonding (comparison between testes and prediction models).

\begin{tabular}{|c|c|c|c|c|c|c|c|c|c|c|c|}
\hline \multirow[b]{2}{*}{ Reference } & \multirow[b]{2}{*}{ Beam } & \multicolumn{2}{|c|}{ Exp. Results } & \multicolumn{8}{|c|}{ Comparison results, $\boldsymbol{P}_{u, e x p} / \boldsymbol{P}_{u, c a l}$} \\
\hline & & $\begin{array}{l}P_{u, e x p} \\
(k N)\end{array}$ & $\begin{array}{l}\text { Failure } \\
\text { modet }\end{array}$ & $\begin{array}{l}\text { Jansze } \\
(1997)\end{array}$ & $\begin{array}{l}\text { Chen \& } \\
\text { Teng } \\
\text { (2001) }\end{array}$ & $\begin{array}{c}\text { Smith \& } \\
\text { Teng } \\
\text { (2002b)* }\end{array}$ & $\begin{array}{l}\text { Colotti et } \\
\text { al. } \\
(2004)\end{array}$ & $\begin{array}{l}\text { Teng \& } \\
\text { Yao } \\
\text { (2007)‡ }\end{array}$ & $\begin{array}{c}\text { fib bulletin } 14 \\
\text { (International } \\
\text { Federation for } \\
\text { Structural } \\
\text { Concrete, 2001) }\end{array}$ & $\begin{array}{l}\text { CS TR55 } \\
\text { (Concrete } \\
\text { Society, } \\
\text { 2012) }\end{array}$ & $\begin{array}{l}\text { CNR- } \\
\text { DT200 } \\
\text { (CNR, } \\
\text { 2013) }\end{array}$ \\
\hline \multirow{4}{*}{$\begin{array}{l}\text { Nguyen et al. } \\
\text { (2001) }\end{array}$} & A950 & 86.0 & CCS & 1.46 & 1.16 & 1.30 & 1.71 & 1.48 & 0.90 & 1.08 & 0.95 \\
\hline & A1100 & 82.0 & CCS & 1.31 & 1.19 & 1.32 & 1.33 & 1.31 & 0.92 & 1.11 & 0.97 \\
\hline & A1150 & 79.0 & CCS & 1.27 & 1.22 & 1.36 & 1.26 & 1.30 & 0.94 & 1.14 & 1.00 \\
\hline & B2 & 86.0 & CCS & 1.75 & 1.43 & 1.94 & 3.19 & 1.85 & 1.17 & 1.36 & 1.22 \\
\hline \multirow{4}{*}{$\begin{array}{l}\text { Rahimi \& } \\
\text { Hutchinson } \\
\text { (2001) }\end{array}$} & A4 & 86.0 & CCS & 0.94 & 1.52 & 0.94 & 0.79 & 0.89 & 1.24 & 1.46 & 1.15 \\
\hline & A6 & 82.0 & CCS & 0.90 & 1.47 & 0.90 & 0.59 & 0.87 & 1.13 & 1.41 & 1.00 \\
\hline & A8 & 79.0 & CCS & 0.99 & 1.61 & 0.99 & 0.83 & 0.94 & 1.31 & 1.54 & 1.21 \\
\hline & B5 & 86.0 & CCS & 1.06 & 1.73 & 1.05 & 0.68 & 1.00 & 1.32 & 1.65 & 1.17 \\
\hline $\begin{array}{l}\text { Buyukozturk et al. } \\
\text { (2002) }\end{array}$ & S1PF1M & 168.5 & CCS & 1.33 & 1.07 & 1.83 & 2.07 & 1.81 & 0.91 & 1.10 & 1.00 \\
\hline \multirow{6}{*}{$\begin{array}{l}\text { Smith \& Teng } \\
\quad \text { (2003) }\end{array}$} & $1 \mathrm{~A}$ & 168.5 & CCS & 1.24 & 0.93 & 1.17 & 0.87 & 1.02 & 0.72 & 0.79 & 0.68 \\
\hline & $1 B$ & 168.5 & CCS & 1.36 & 1.55 & 1.96 & 0.73 & 1.10 & 1.21 & 1.33 & 1.14 \\
\hline & $2 \mathrm{~A}$ & 168.5 & CCS & 1.41 & 0.66 & 0.83 & 1.22 & 0.99 & 0.54 & 0.60 & 0.50 \\
\hline & $2 B$ & 168.5 & CCS & 1.45 & 1.19 & 1.48 & 0.69 & 0.97 & 0.97 & 1.07 & 0.90 \\
\hline & $3 A$ & 168.5 & CCS & 1.07 & 1.12 & 1.40 & 0.77 & 1.02 & 0.92 & 1.01 & 0.85 \\
\hline & $3 B$ & 168.5 & CCS & 1.62 & 1.37 & 1.72 & 0.66 & 0.97 & 1.13 & 1.24 & 1.05 \\
\hline \multirow{2}{*}{$\begin{array}{l}\text { Valcuende et al. } \\
\qquad(2003)\end{array}$} & A-S1 & 168.5 & CCS & 1.61 & 1.51 & 1.95 & 1.44 & 1.71 & 1.19 & 1.42 & 1.29 \\
\hline & B-S1 & 168.5 & CCS & 1.51 & 1.33 & 1.71 & 1.26 & 1.49 & 1.05 & 1.25 & 1.13 \\
\hline \multirow{10}{*}{$\begin{array}{l}\text { Brena et al. } \\
\text { (2003) }\end{array}$} & A1-I & 168.5 & CCS & 1.61 & 1.26 & 1.09 & 0.91 & 0.75 & 1.15 & 1.24 & 1.16 \\
\hline & $A 2-I$ & 168.5 & CCS & 1.42 & 1.28 & 1.23 & 0.75 & 0.93 & 1.14 & 1.25 & 1.16 \\
\hline & A3-I & 168.5 & CCS & 0.79 & 1.42 & 1.42 & 0.83 & 1.05 & 1.24 & 1.38 & 1.25 \\
\hline & A4-I & 168.5 & CCS & 0.89 & 1.32 & 1.34 & 0.70 & 0.96 & 1.13 & 1.26 & 1.07 \\
\hline & A5-I & 168.5 & CCS & 1.03 & 1.38 & 1.28 & 0.79 & 0.84 & 1.15 & 1.27 & 1.05 \\
\hline & A1-II & 168.5 & $\mathrm{CCS}$ & 0.97 & 1.13 & 1.25 & 0.96 & 0.93 & 1.07 & 1.12 & 1.08 \\
\hline & A2-II & 168.5 & CCS & 0.93 & 1.18 & 1.39 & 1.06 & 1.15 & 1.10 & 1.16 & 1.11 \\
\hline & A3-II & 168.5 & CCS & 0.85 & 1.17 & 1.38 & 1.02 & 1.14 & 1.07 & 1.15 & 1.07 \\
\hline & A4-II & 168.5 & $\mathrm{CCS}$ & 0.94 & 1.27 & 1.51 & 1.00 & 1.20 & 1.14 & 1.23 & 1.10 \\
\hline & A5-II & 168.5 & CCS & 0.94 & 1.24 & 1.41 & 0.86 & 1.00 & 1.11 & 1.18 & 1.05 \\
\hline \multirow{3}{*}{$\begin{array}{l}\text { Gao et al. } \\
\text { (2004a) }\end{array}$} & $1 \mathrm{~T} 6 \mathrm{LN}$ & 116.2 & CCS & 1.03 & 1.74 & 1.79 & 0.80 & 1.23 & 1.17 & 1.42 & 1.06 \\
\hline & $2 \mathrm{~T} 6 \mathrm{LN}$ & 135.9 & CCS & 0.96 & 1.88 & 1.92 & 0.84 & 1.27 & 1.30 & 1.54 & 1.16 \\
\hline & $2 T 4 L N$ & 133.3 & CCS & 1.24 & 1.84 & 1.88 & 0.83 & 1.19 & 1.42 & 1.59 & 1.27 \\
\hline \multirow{2}{*}{$\begin{array}{l}\text { Gao et al. } \\
\text { (2004b) }\end{array}$} & AO & 80.7 & PED & 1.33 & 1.27 & 1.37 & 1.10 & 0.97 & 1.19 & 1.25 & 1.19 \\
\hline & BO & 86.4 & CCS & 1.30 & 1.29 & 1.46 & 1.18 & 1.24 & 1.15 & 1.24 & 1.16 \\
\hline \multirow{2}{*}{$\begin{array}{l}\text { Grace and Singh } \\
\text { (2005) }\end{array}$} & $\mathrm{Bb} 1$ & 136.6 & PED & 1.56 & 1.47 & 1.32 & 1.48 & 1.29 & 1.02 & 1.23 & 1.01 \\
\hline & Bb3 & 133.5 & PED & 1.67 & 1.24 & 1.29 & 1.44 & 1.01 & 1.05 & 1.10 & 1.02 \\
\hline \multirow{8}{*}{$\begin{array}{c}\text { Pham \& Al- } \\
\text { Mahaidi (2006) }\end{array}$} & E1a & 141.4 & PED & 1.35 & 1.34 & 1.41 & 1.21 & 1.24 & 0.99 & 1.24 & 0.90 \\
\hline & E1b & 149.2 & PED & 1.32 & 1.41 & 1.49 & 1.27 & 1.30 & 1.05 & 1.31 & 0.95 \\
\hline & E2a & 102.8 & PED & 1.51 & 0.97 & 1.03 & 1.42 & 1.07 & 0.72 & 0.90 & 0.65 \\
\hline & $E 2 b$ & 106.8 & PED & 1.59 & 1.01 & 1.07 & 1.48 & 1.12 & 0.75 & 0.94 & 0.68 \\
\hline & E3a & 132.0 & PED & 1.30 & 1.58 & 1.51 & 0.89 & 1.29 & 1.17 & 1.46 & 1.06 \\
\hline & E3b & 130.4 & PED & 1.35 & 1.56 & 1.49 & 0.88 & 1.27 & 1.15 & 1.45 & 1.05 \\
\hline & E4a & 158.0 & PED & 1.67 & 1.50 & 1.58 & 1.35 & 1.38 & 1.11 & 1.39 & 1.01 \\
\hline & E4b & 122.4 & PED & 1.65 & 1.16 & 1.22 & 1.04 & 1.07 & 0.86 & 1.07 & 0.78 \\
\hline
\end{tabular}


Table 2 (cont.). Database of beams failed by plate-end debonding (comparison between testes and prediction models).

\begin{tabular}{|c|c|c|c|c|c|c|c|c|c|c|c|}
\hline \multirow[b]{2}{*}{ Reference } & \multirow[b]{2}{*}{ Beam } & \multicolumn{2}{|c|}{ Exp. Results } & \multicolumn{8}{|c|}{ Comparison results, $\boldsymbol{P}_{u, \exp } / \boldsymbol{P}_{u, c a l}$} \\
\hline & & $\begin{array}{l}P_{u, e x p} \\
(k N)\end{array}$ & $\begin{array}{l}\text { Failure } \\
\text { modet }\end{array}$ & $\begin{array}{l}\text { Jansze } \\
(1997)\end{array}$ & $\begin{array}{c}\text { Chen \& } \\
\text { Teng } \\
(2001)\end{array}$ & $\begin{array}{c}\text { Smith \& } \\
\text { Teng } \\
\text { (2002b)* }\end{array}$ & $\begin{array}{l}\text { Colotti et al. } \\
\qquad(2004)\end{array}$ & $\begin{array}{c}\text { Teng \& } \\
\text { Yao } \\
(2007) \ddagger\end{array}$ & $\begin{array}{l}\text { fib bulletin } 14 \\
\text { (International } \\
\text { Federation for } \\
\text { Structural } \\
\text { Concrete, } \\
\text { 2001) }\end{array}$ & $\begin{array}{l}\text { CS TR55 } \\
\text { (Concrete } \\
\text { Society, } \\
\text { 2012) }\end{array}$ & $\begin{array}{l}\text { CNR- } \\
\text { DT200 } \\
\text { (CNR, } \\
2013)\end{array}$ \\
\hline \multirow{3}{*}{$\begin{array}{l}\text { Pham \& Al- } \\
\text { Mahaidi (2006) }\end{array}$} & E5a & 126.6 & PED & 1.35 & 1.26 & 1.27 & 1.08 & 1.16 & 0.93 & 1.17 & 0.84 \\
\hline & E5b & 126.4 & PED & 1.35 & 1.26 & 1.26 & 1.08 & 1.15 & 0.93 & 1.17 & 0.84 \\
\hline & E3b2 & 120.0 & PED & 1.71 & 1.62 & 1.54 & 0.91 & 1.32 & 1.19 & 1.50 & 1.08 \\
\hline \multirow{6}{*}{$\begin{array}{c}\text { Benjeddou et al. } \\
\text { (2007) }\end{array}$} & RB1 & 40.11 & CCS & 0.91 & 1.33 & 1.08 & 0.72 & 1.10 & 0.98 & 1.20 & 0.98 \\
\hline & RB2 & 37.66 & CCS & 0.86 & 1.25 & 1.02 & 0.68 & 1.03 & 0.92 & 1.13 & 0.92 \\
\hline & RB3 & 32.10 & CCS & 0.73 & 1.07 & 0.87 & 0.58 & 0.88 & 0.78 & 0.96 & 0.79 \\
\hline & RB4 & 30.75 & CCS & 0.70 & 1.02 & 0.83 & 0.56 & 0.84 & 0.75 & 0.92 & 0.75 \\
\hline & RB5 & 30.10 & PED & 0.68 & 1.02 & 0.81 & 0.66 & 0.89 & 0.82 & 0.99 & 0.93 \\
\hline & RB6 & 37.37 & CCS & 0.70 & 1.02 & 0.83 & 0.55 & 0.80 & 0.74 & 0.91 & 0.73 \\
\hline \multirow[t]{2}{*}{$\begin{array}{l}\text { Esfahani et al. } \\
\qquad(2007)\end{array}$} & $\begin{array}{l}\text { B3-12D- } \\
\text { 2L15 }\end{array}$ & 70.94 & CCS & 1.18 & 1.20 & 1.18 & 0.69 & 0.95 & 0.98 & 1.07 & 0.94 \\
\hline & $\begin{array}{l}\text { B4-12D- } \\
\text { 3L15 }\end{array}$ & 74.44 & CCS & 1.24 & 1.32 & 1.24 & 0.72 & 1.09 & 0.96 & 1.10 & 0.91 \\
\hline \multirow[t]{4}{*}{ Yao \& Teng (2007) } & CS-B & 81.5 & CCS & 1.54 & 1.42 & 1.76 & 0.71 & 1.03 & 1.01 & 1.18 & 0.96 \\
\hline & CS-L3-B & 78.5 & CCS & 1.45 & 1.38 & 1.66 & 0.66 & 1.08 & 0.92 & 1.15 & 0.84 \\
\hline & $\begin{array}{c}\text { CS- } \\
\text { W100-B }\end{array}$ & 80.9 & CCS & 1.43 & 1.20 & 1.63 & 0.74 & 0.94 & 1.07 & 1.15 & 1.05 \\
\hline & CP-B & 76.1 & CCS & 1.35 & 1.28 & 1.55 & 0.61 & 1.07 & 0.85 & 1.06 & 0.82 \\
\hline \multirow[t]{3}{*}{ Ceroni (2010) } & A3 & 40.0 & PED & 1.34 & 1.57 & 1.02 & 0.82 & 1.21 & 1.27 & 1.36 & 1.22 \\
\hline & B2 & 49.2 & PED & 1.50 & 1.32 & 1.11 & 1.57 & 1.13 & 1.23 & 1.28 & 1.20 \\
\hline & B3 & 48.2 & PED & 1.47 & 1.36 & 1.09 & 1.54 & 1.35 & 1.12 & 1.18 & 1.09 \\
\hline \multirow{3}{*}{$\begin{array}{l}\text { Al-Tamimi et al. } \\
\text { (2011) }\end{array}$} & B85P & 60.7 & CCS & 1.12 & 1.21 & 1.16 & 0.59 & 0.98 & 0.84 & 1.05 & 0.78 \\
\hline & B70P & 47.1 & CCS & 1.03 & 0.94 & 0.90 & 0.56 & 0.86 & 0.65 & 0.82 & 0.61 \\
\hline & B25P & 51.9 & PED & 1.32 & 1.17 & 0.99 & 1.82 & 1.53 & 0.78 & 0.97 & 0.68 \\
\hline \multirow[t]{2}{*}{ Li et al. (2013) } & B11 & 63.3 & PED & 1.06 & 1.28 & 1.05 & 0.77 & 0.85 & 1.14 & 1.22 & 1.10 \\
\hline & B21 & 76.3 & CCS & 1.15 & 1.10 & 1.18 & 1.06 & 1.23 & 0.98 & 1.05 & 0.96 \\
\hline $\begin{array}{l}\text { Sadrmomtazi et al. } \\
\text { (2014) }\end{array}$ & $\mathrm{C} 2$ & 75.8 & PED & 1.53 & 1.30 & 1.85 & 1.18 & 0.92 & 1.14 & 1.23 & 1.07 \\
\hline $\begin{array}{l}\text { Al-Saawani et al. } \\
\text { (2015) }\end{array}$ & $\begin{array}{l}\text { S-0.5- } \\
35-360\end{array}$ & 235.1 & CCS & 1.27 & 2.00 & 1.23 & 0.74 & 1.24 & 1.40 & 1.75 & 1.33 \\
\hline \multirow{2}{*}{$\begin{array}{l}\text { Hasnat et al. } \\
\text { (2016) }\end{array}$} & $S(A T 1) C$ & 100.0 & CCS & 1.59 & 1.54 & 1.75 & 0.72 & 1.15 & 1.29 & 1.48 & 1.30 \\
\hline & $\mathrm{B}(\mathrm{AT} 1) \mathrm{C}$ & 101.6 & CCS & 1.62 & 1.56 & 1.79 & 0.74 & 1.18 & 1.32 & 1.51 & 1.33 \\
\hline \multirow{6}{*}{$\begin{array}{c}\text { Skuturna \& } \\
\text { Valivonis (2016) }\end{array}$} & BC1-1 & 79.0 & CCS & 1.85 & 1.36 & 2.11 & 0.97 & 0.89 & 1.22 & 1.30 & 1.17 \\
\hline & BC1-2 & 78.0 & CCS & 1.82 & 1.35 & 2.08 & 0.96 & 0.88 & 1.20 & 1.28 & 1.15 \\
\hline & BC2-1 & 79.5 & CCS & 1.86 & 1.37 & 2.12 & 0.98 & 0.89 & 1.23 & 1.31 & 1.18 \\
\hline & BC3-1 & 68.0 & CCS & 1.80 & 1.25 & 2.06 & 0.97 & 0.87 & 1.11 & 1.18 & 1.08 \\
\hline & BC4-1 & 44.0 & CCS & 1.34 & 1.47 & 1.45 & 0.71 & 0.83 & 1.18 & 1.34 & 1.10 \\
\hline & BC4-2 & 48.0 & CCS & 1.46 & 1.60 & 1.58 & 0.77 & 0.91 & 1.29 & 1.46 & 1.20 \\
\hline \multirow{2}{*}{$\begin{array}{c}\text { Jeevan \& Reddy } \\
\text { (2018) }\end{array}$} & EBL-1 & 86.00 & CCS & 1.09 & 1.34 & 0.96 & 0.95 & 1.02 & 1.18 & 1.39 & 1.22 \\
\hline & Average $=$ & & & 1.30 & 1.48 & 1.44 & 1.06 & 1.18 & 1.19 & 1.37 & 1.16 \\
\hline \multicolumn{4}{|c|}{ Coefficient of variation $=$} & $33.8 \%$ & $22.8 \%$ & $26.1 \%$ & $31.6 \%$ & $23.9 \%$ & $19.9 \%$ & $20.8 \%$ & $19.7 \%$ \\
\hline \multicolumn{4}{|c|}{ Number of unsafe predictions (percentage) $=$} & $\begin{array}{c}43 \\
(27.2 \%)\end{array}$ & $\begin{array}{c}4 \\
(2.5 \%)\end{array}$ & $\begin{array}{c}17 \\
(10.8 \%)\end{array}$ & $\begin{array}{c}71 \\
(44.9 \%)\end{array}$ & $\begin{array}{c}46 \\
(29.1 \%)\end{array}$ & $\begin{array}{c}34 \\
(21.5 \%)\end{array}$ & $\begin{array}{c}11 \\
(7.0 \%)\end{array}$ & $\begin{array}{c}35 \\
(22.2 \%)\end{array}$ \\
\hline
\end{tabular}

$* V_{c}$ is calculated using the Australian code equation [AS 3600, 1988]; + CCS: concrete cover separation; PED: plate-end interfacial debonding; $¥ V_{c}$ is calculated using Oehlers et al.'s $(2004,2005)$ model. Figure 4. Comparison of test results with Jansze's model predictions. 


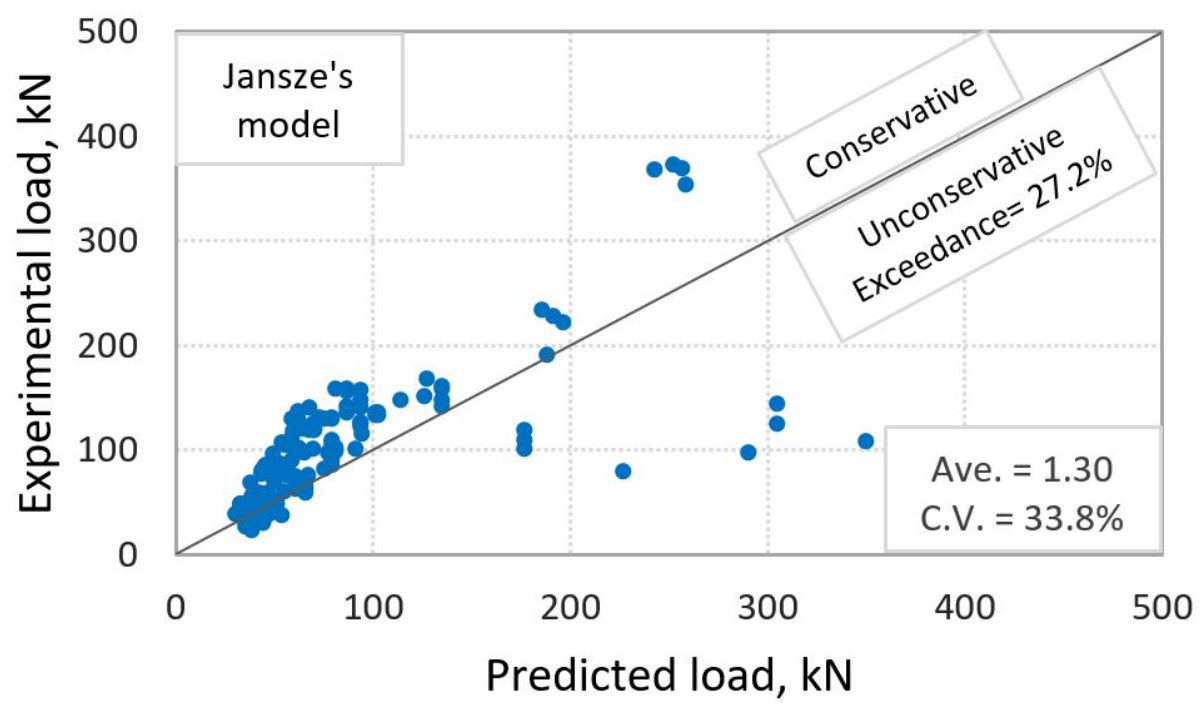

Figure 4. Comparison of test results with Jansze's model predictions.

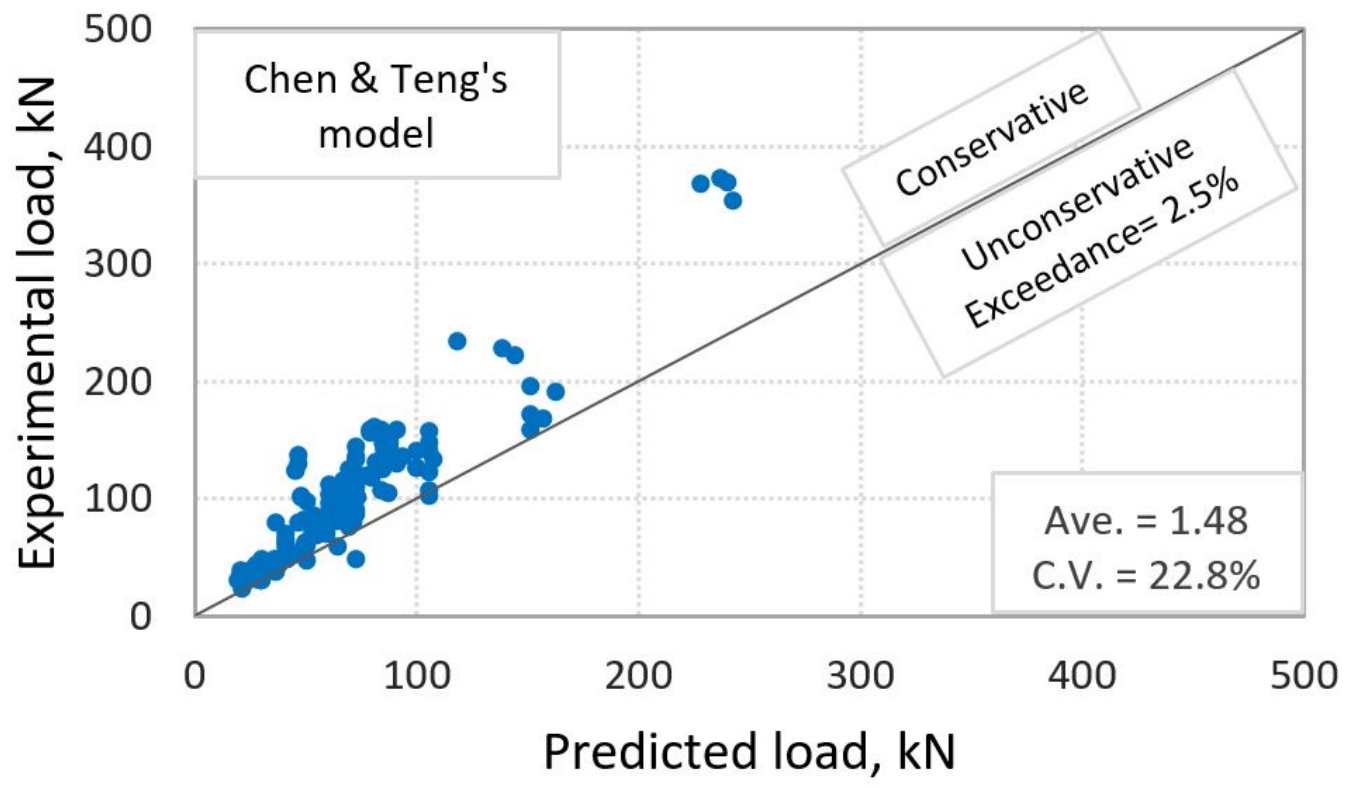

Figure 5. Comparison of test results with Chen and Teng's model predictions. 


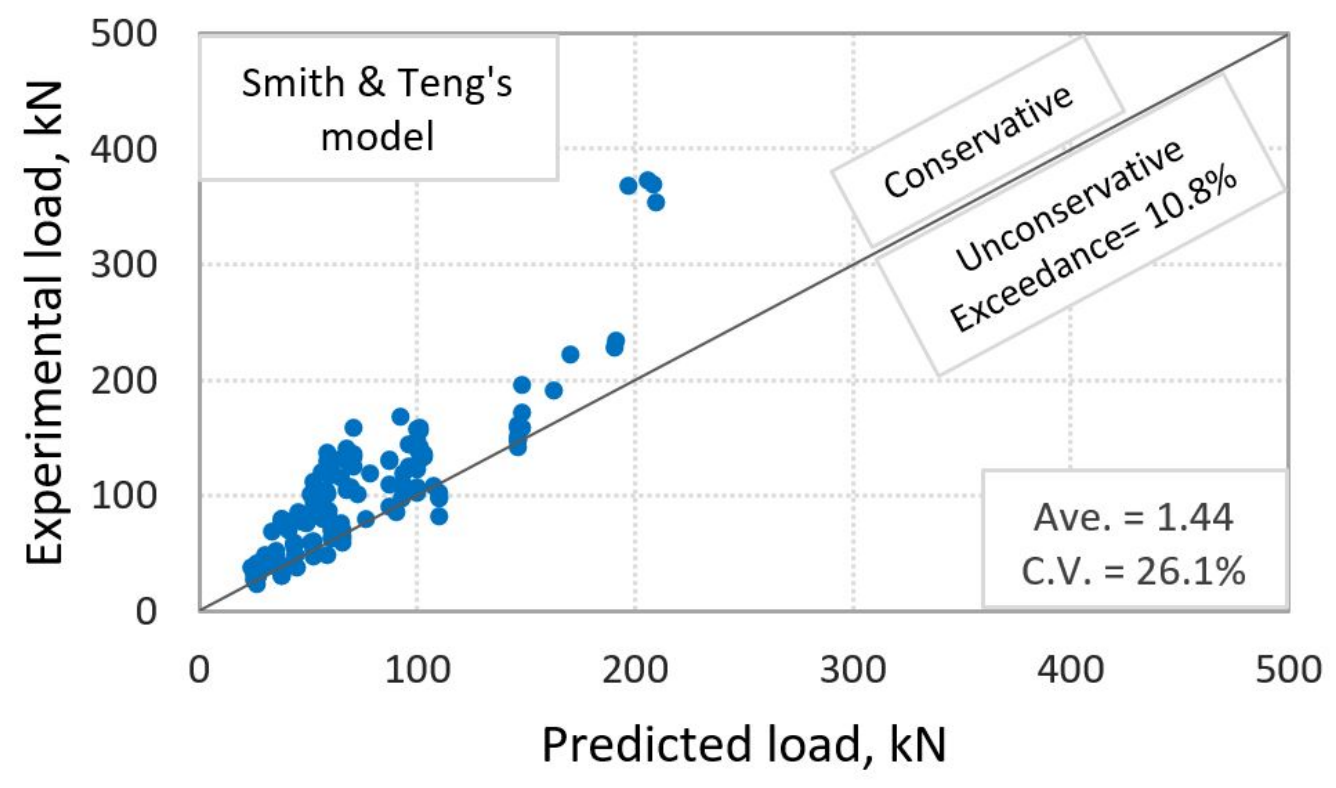

Figure 6. Comparison of test results with Smith and Teng's model predictions.

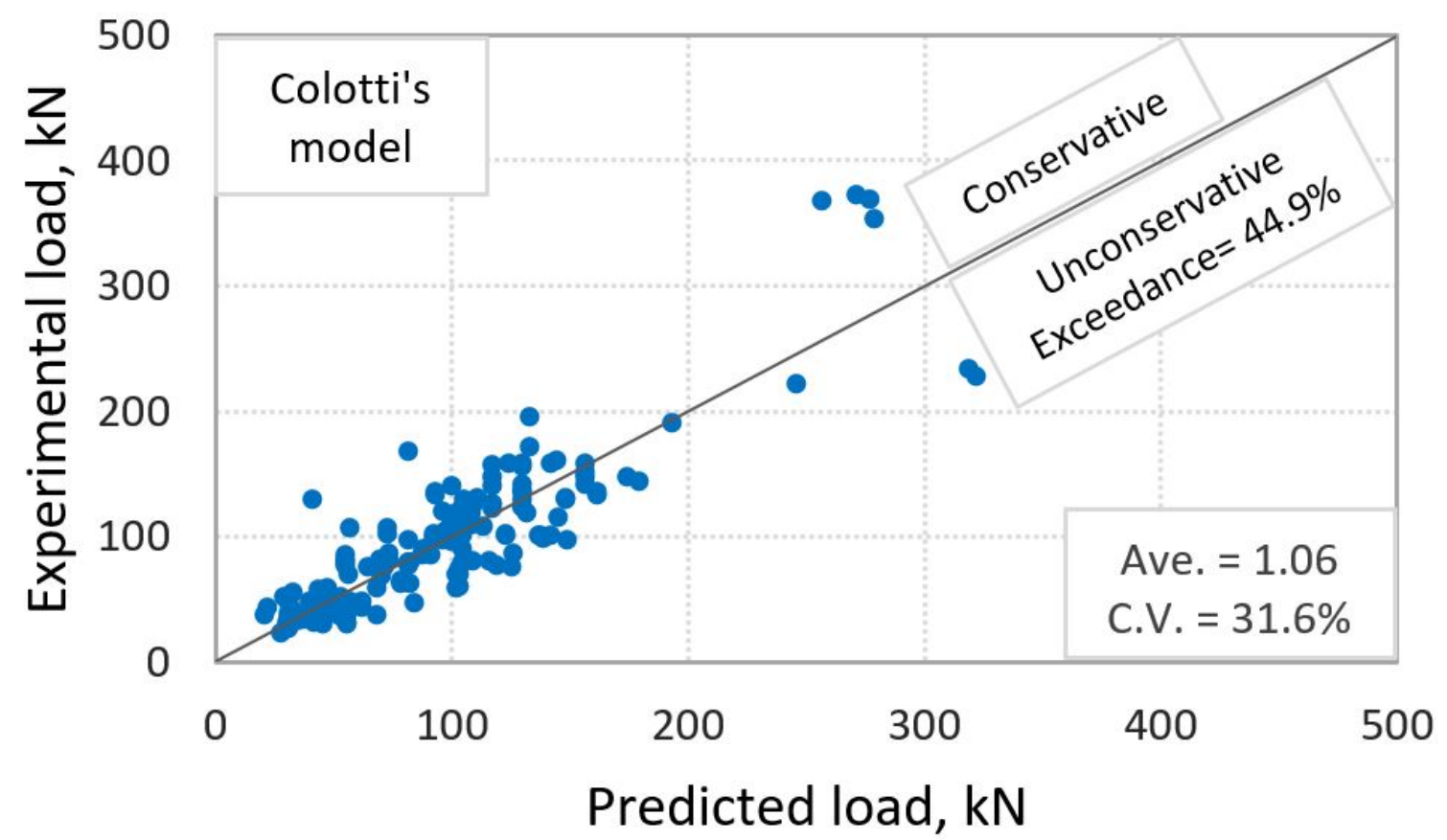

Figure 7. Comparison of test results with Colotti's model predictions. 


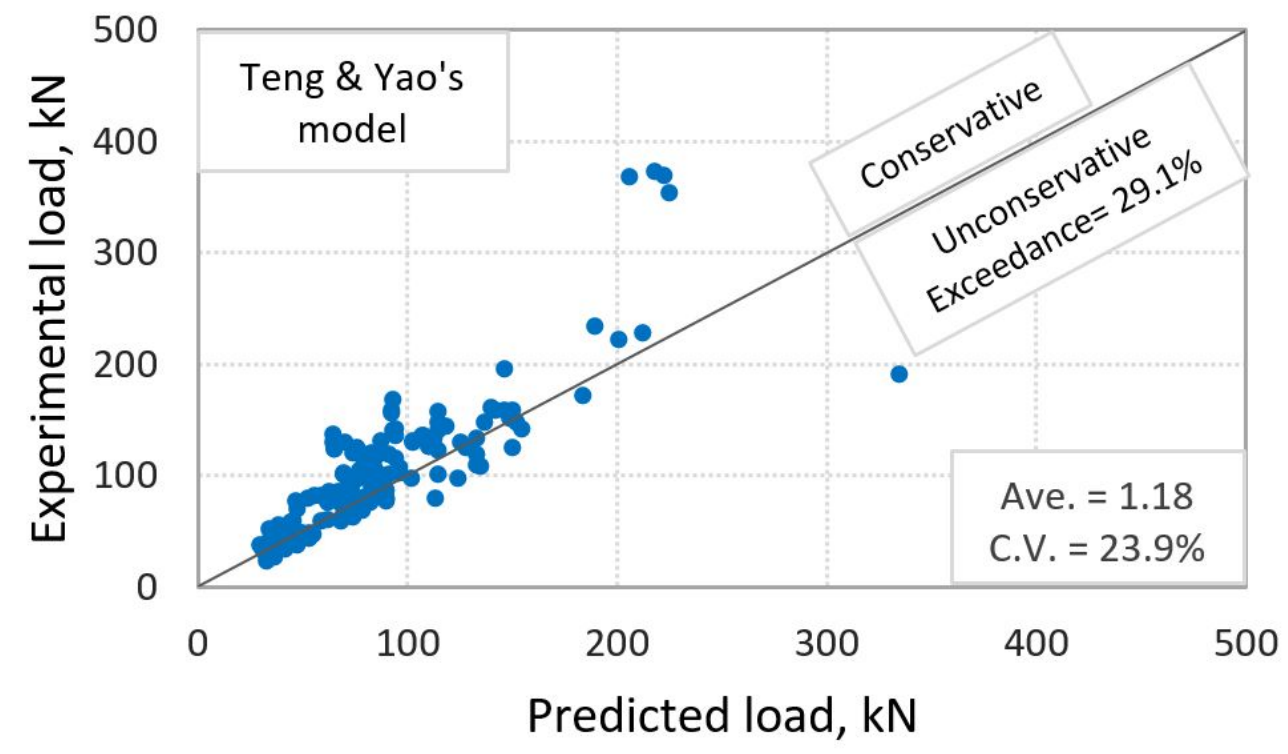

Figure 8. Comparison of test results with Teng and Yao's model predictions.

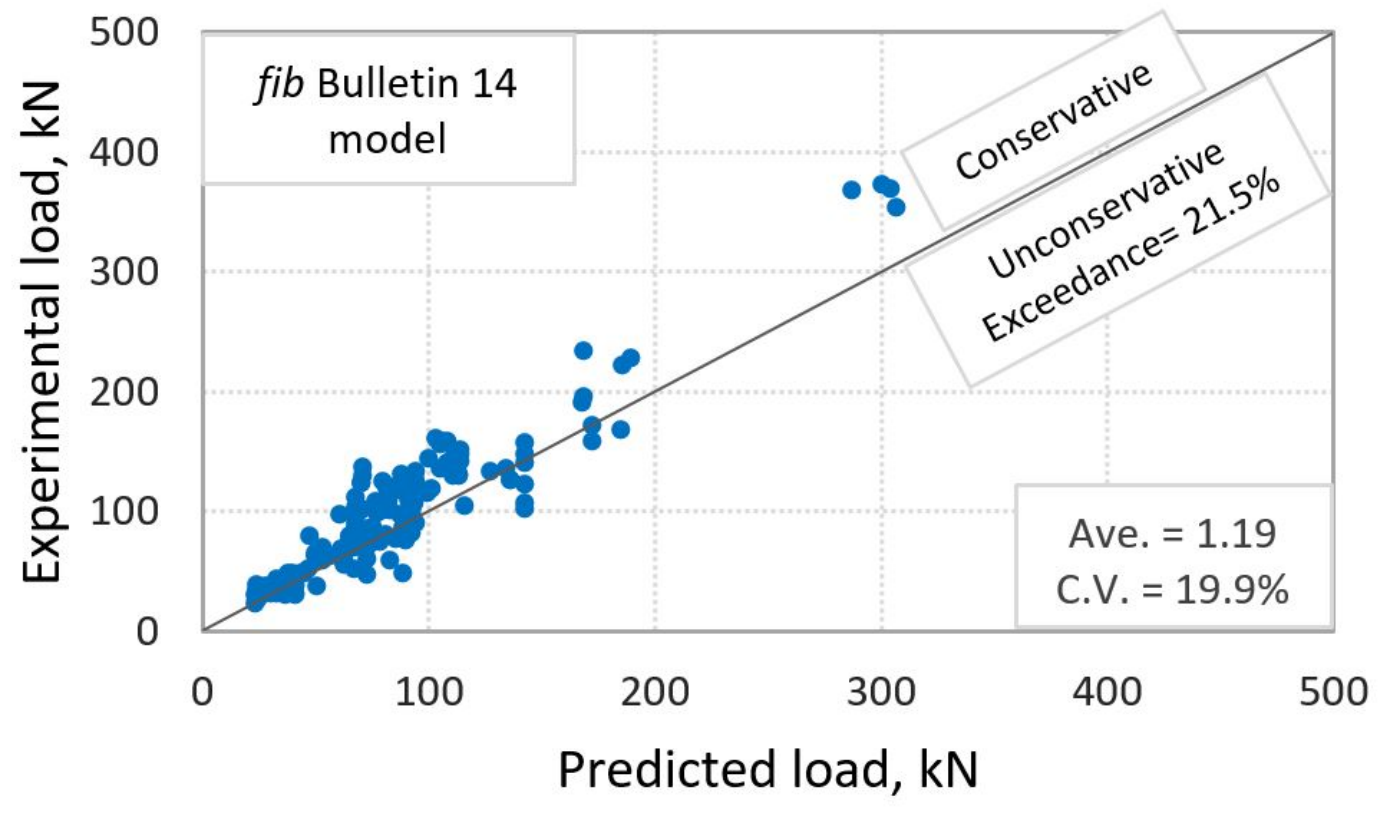

Figure 9. Comparison of test results with fib Bulletin 14 model predictions. 


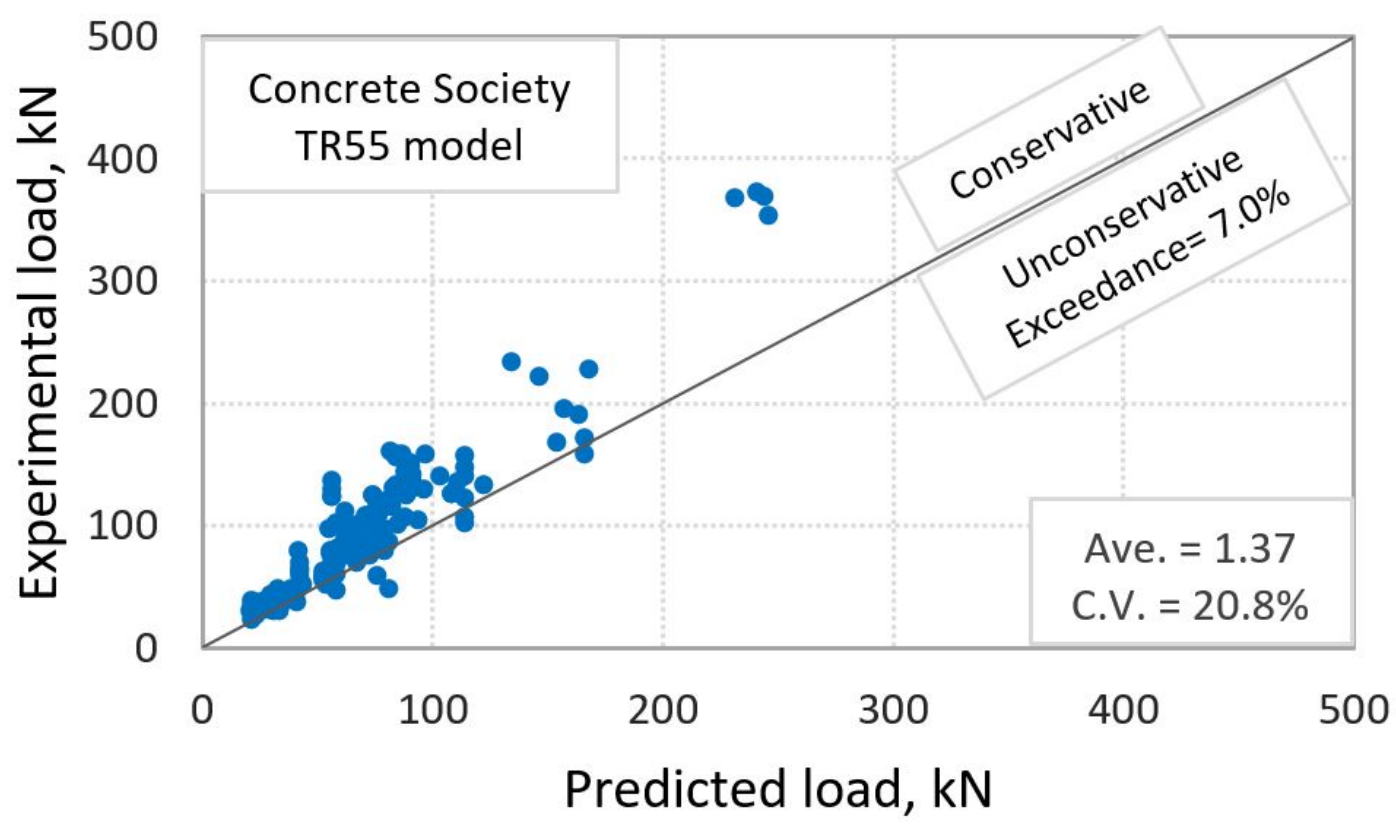

Figure 10. Comparison of test results with TR55 model predictions.

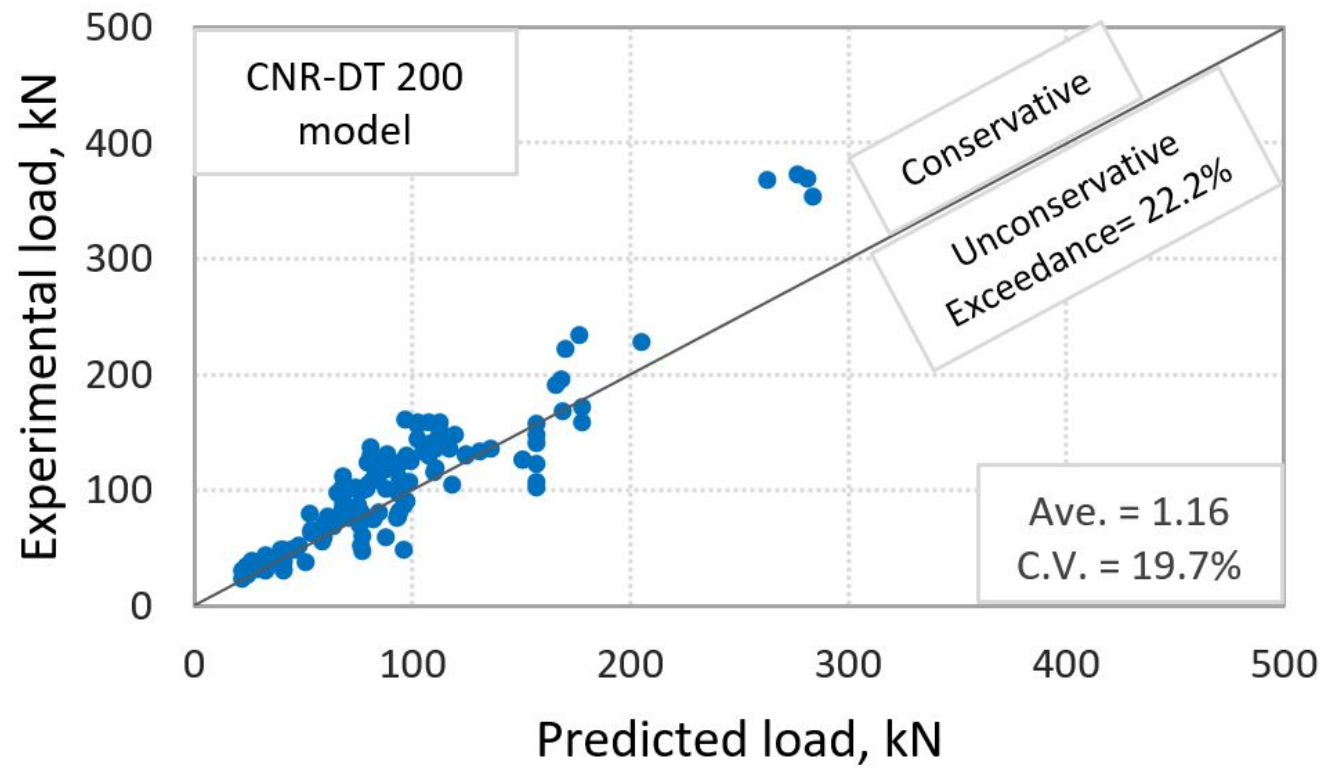

Figure 11. Comparison of test results with CNR-DT 200 model predictions. 
laminate should be terminated at least a distance equal to the development length, $L_{d f}$, past the point along the span at which the resisted moment falls below the cracking moment, $M_{c r}$. A graphical representation of such criteria is shown in Figure 12. The figure shows that the distance from the support to the $M_{c r}$ section is $X_{c r}$. At the design stage, the section at the cracking moment along the beam can be determined from the bending moment diagram corresponding to the factored load. Then, the length of FRP laminates is determined to be extended beyond the cracking moment section by a distance at least equal to $L_{d f}$. This criterion can be examined against the established database used previously in evaluating the PE prediction models listed in Table 2. At the experimental failure loads, the distance along the beam span from the support to the section corresponding to the cracking moment, $X_{c r}$, was determined for the 158 strengthened beams included in the database. This $X_{c r}$ distance will be compared with the $L_{d f}+L_{u p}$ distance for each beam, where $L_{u p}$ is the unplated length of the beam measured from the support to the plate end as shown in Figure 12. The development length of FRP laminates, $L_{d f}$, can be calculated using the equation given by the $\mathrm{ACl} 440.2$ document (ACl Committee 440, 2017), as follows:

$L_{d f}=\frac{\sqrt{n_{f} E_{f} t_{f}}}{\sqrt{f_{c}^{\prime}}}$

where $n_{f}$ is the number of FRP plies, $E_{f}$ is the modulus of elasticity of FRP, $t_{f}$ is thickness of FRP ply, and $f_{c}^{\prime}$ is the specified compressive strength of concrete.

Figure 13 plots the relationship between the values of $X_{c r}$ and $L_{d f}+L_{u p}$ for the beams in the database. Values of $X_{c r}$ below the $45^{\circ}$ line show that the term $X_{c r}$ is less than the term $L_{d f}+L_{u p}$ which indicates that the corresponding beam is expected to fail by PE debonding because the extended length of FRP laminates past the cracking moment section is less than $L_{d f}$. It can be seen from Figure 13 that almost all the data points were located below the $45^{\circ}$ line. This indicates that this criterion provided good predictions of the PE debonding failure for almost all the beams in the database. This result of comparison means that if this criterion is considered during the design stage, it could prevent any premature failure due to PE debonding.

\subsection{Approach related to the shear force limit}

The formation of shear cracks near the plate end region is responsible for the initiation of CCS failure. Therefore, CCS could be addressed by estimating the capacity of the section against the formation of shear cracks. Some design codes [ACl 440.2 2017; International Federation for Structural Concrete, 2001; Concrete Society 2012; AS 5100.8, 2017] suggest a limit for the shear force at the FRP plate end region in a strengthened member below which PE debonding failure could be avoided. This shear force is proposed as a percentage of the shear capacity of the RC section, which is considered in some codes as the contribution of the shear strength of concrete alone, while others suggest an effective contribution from the steel stirrups in addition to the shear capacity of concrete. The different limits of the shear force at the FRP plate end region for a strengthened member as suggested by different design codes and guidelines are listed in Table 3. The listed codes include ACl 440.2 guide (ACl Committee 440, 2017), Australian Standard AS 5100.8 (2017), the Concrete Society Technical report No. 55 (Concrete Society, 2012), and the fib bulletin 14 (International Federation for Structural Concrete, 2001).

These different limits were examined against the 158 beams included in the database as shown in Figure 14. The figure shows the ratio $V_{\text {Exp }} / V_{\text {Limit }}$ between the experimental shear load at PE debonding failure, $V_{\text {Exp, }}$ to the limit of the shear force, $V_{\text {Limit }}$, of the beam at the region of FRP plate end as suggested by the different criteria. In this figure, the ratio $V_{\text {Exp }} / V_{\text {Limit }}>1.0$ indicates that the design criterion anticipates that the strengthened beam will fail by $\mathrm{PE}$ debonding, while values of $V_{\text {Exp }} / V_{\text {Limit }} \leq 1.0$ indicate that PE debonding failure would not occur. The figure indicates that both $\mathrm{ACl} 440.2$ ( $\mathrm{ACl}$ Committee 440, 2017) and fib bulletin 14 (International Federation for Structural Concrete, 2001) predicted the PE debonding failure for the beams in the database as all the data points were above 1 . It can be noted that the limits provided by both codes represent fraction of the cracking shear strength of the beams resulting in very small values of $V_{\text {Limit. }}$. These very conservative values of the shear force limits at PE debonding failure recommended by both codes are not reliable for use in design and diminish the effectiveness of FRP-strengthening. On the other hand, 
the limits of the shear force at PE debonding suggested by AS 5100.8 (2017) and TR55 (Concrete Society (2012) could predict the PE debonding failure for only $37 \%$ and $38 \%$ of the beams in the database, respectively.

\section{MITIGATION OF PE DEBONDING}

It is worth noting that the precautions suggested by some design codes and guidelines to avoid PE debonding decrease the enhancement in the ultimate strength due to FRP-strengthening. This indicates the need to find effective measures

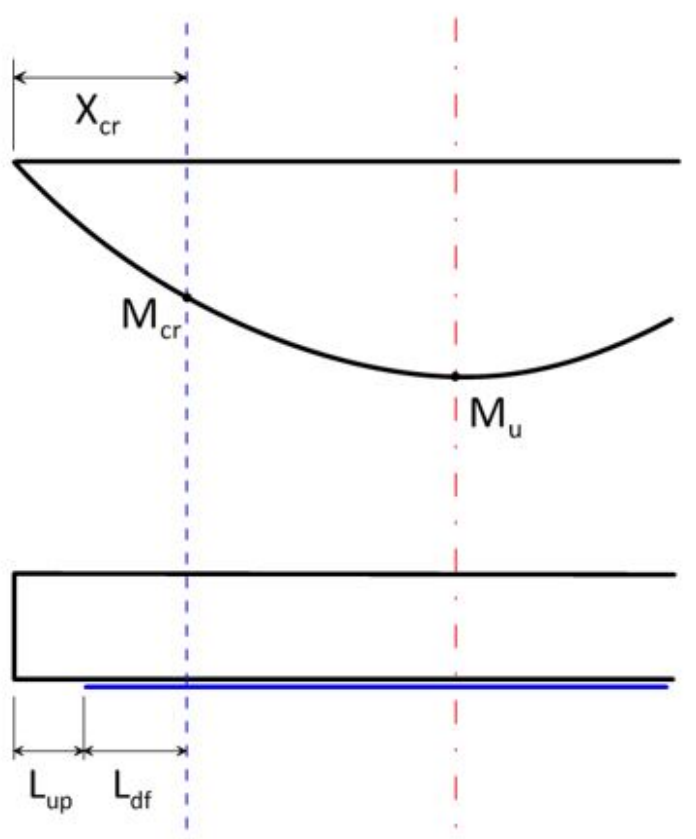

(a) For a single-ply FRP laminate.

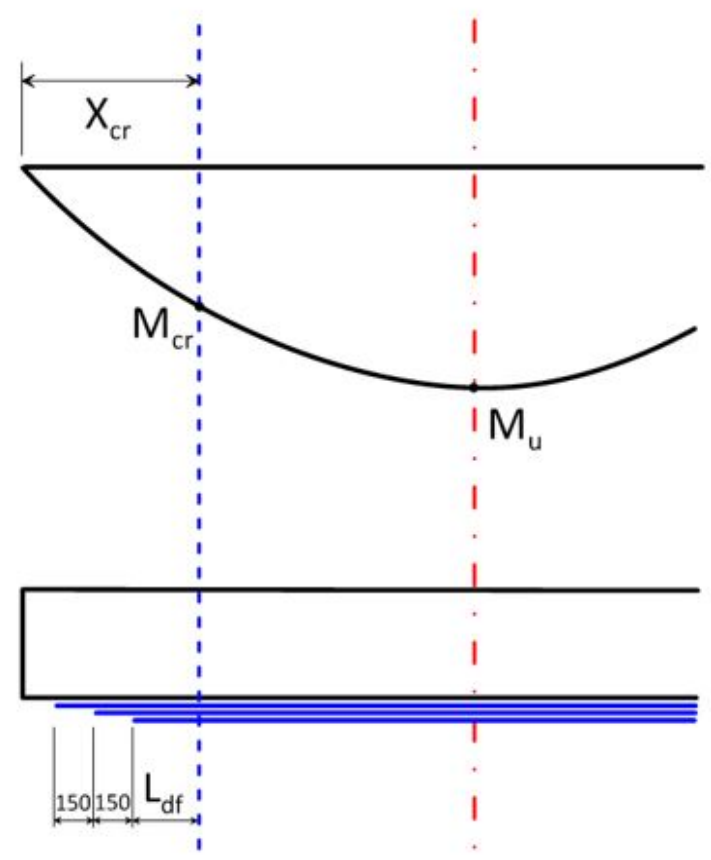

(b) For Multiple-ply FRP laminates.

Figure 12. Graphical representation of FRP termination points as recommended by $\mathrm{ACl} 440.2$ guidelines. 


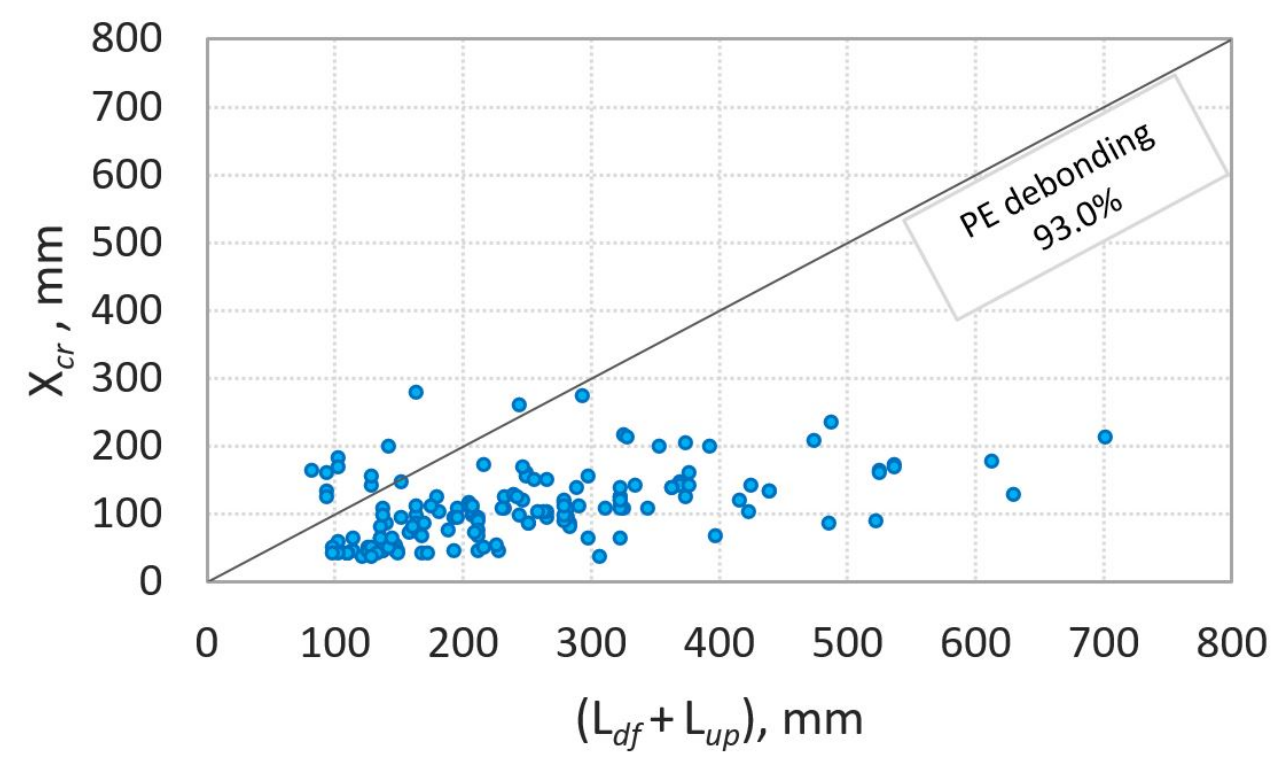

Figure 13. Validation of the $\mathrm{ACl} 440.2 \mathrm{R}$ provisions for the location of FRP cutoff point.

Table 3. Precautions to avoid plate-end debonding in design codes.

\begin{tabular}{|c|c|}
\hline Reference & Provision (Units: $\mathrm{N}$ and $\mathrm{mm}$ ) \\
\hline $\begin{array}{l}\mathrm{ACl} 440.2(\mathrm{ACl} \\
\text { Committee } 440 \text {, } \\
\text { 2017) }\end{array}$ & $\begin{array}{l}V^{*}<0.67 V_{c}, \quad \text { Otherwise U-wrap anchorage must be used as specified by the code. } \\
\text { where } V^{*} \text { represents the factored shear force at the FRP plate end; } V_{c} \text { is the shear capacity of concrete alone } \\
\text { calculated according to } \mathrm{ACl} 318 \text { ( } \mathrm{ACl} \text { Committee } 318,2014 \text { ). }\end{array}$ \\
\hline $\begin{array}{c}\text { AS } 5100.8 \\
(2017)\end{array}$ & $\begin{array}{l}\qquad V^{*}<0.67 V_{u} \\
\text { where } V_{u} \text { is the nominal shear strength of the concrete section including concrete and steel stirrups, calculated in } \\
\text { accordance with AS } 5100.5 \text { (2017). }\end{array}$ \\
\hline $\begin{array}{l}\text { Concrete } \\
\text { Society TR } 55 \\
\text { (Concrete } \\
\text { Society, 2012) }\end{array}$ & $\begin{array}{l}\qquad V^{*}<0.67 V_{R d} \\
\text { where } V_{R d} \text { is the shear strength of the beam section calculated in accordance with Section } 6.2 .3 \text { of BS EN 1992-1-1 } \\
\text { (2004). }\end{array}$ \\
\hline $\begin{array}{l}\text { fib bulletin } 14 \\
\text { (International } \\
\text { Federation for } \\
\quad \text { Structural } \\
\text { Concrete, 2001) }\end{array}$ & $\begin{array}{l}\qquad V^{*} \leq 0.15 f_{c k}^{1 / 3} b_{c} d_{s} \quad \text { Otherwise, shear strengthening should be provided. } \\
\text { where } f_{\mathrm{ck}} \text { is the characteristic strength of concrete calculated according to BS EN 1992-1-1 (2004). }\end{array}$ \\
\hline
\end{tabular}




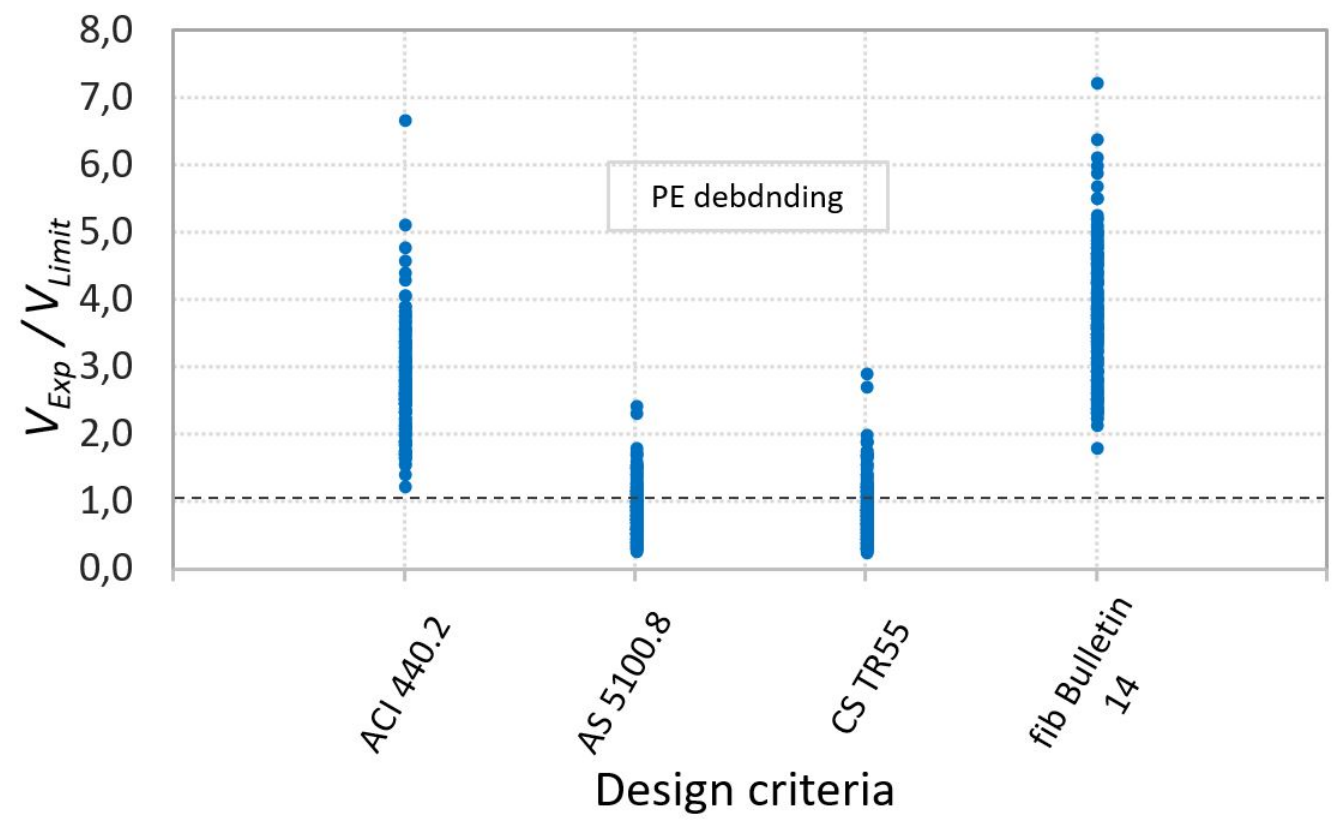

Figure 14. Comparison of design criteria to prevent PE debonding.

to prevent PE debonding failures, which is of great importance to the practical application of FRP composites for flexural strengthening. Recently, research studies have explored different anchorage solutions in an attempt to mitigate/prevent debonding failures. The main role of an anchorage system is to improve the efficiency of the FRP-strengthening system by delaying or preventing the debonding failure (Ceroni et al. 2008). Different anchorage systems for EB FRP have been developed and reported in the literature, which include: mechanical anchorage using steel plates, steel angles, or angle bolts; mechanically fastened FRP; fiber anchors (FRP spike anchors); FRP U-shape wrapping (FRP U-wrap anchors); FRP strips; patch anchors (unidirectional and bidirectional fabrics); near-surface mounted rod anchors; mechanically strengthened substrate (longitudinal chase anchors); and hybrid anchorage systems [Smith and Teng 2003; Brena et al. 2003; Kotynia et al. 2008; Orton et al. 2008; Zhang et al. 2012; Kalfat et al. 2013; Lee and Lopez 2016; Jeevan and Reddy 2018]. Some of these anchorage systems showed successful performance by delaying, and sometimes preventing, debonding failure of the flexural FRP [ACI Committee 440, 2017; Kalfat et al. 2013; Grelle and Sneed 2013]. This allowed the increase in the effective strain developed in the flexural FRP to values up to tensile rupture as obtained from different investigations [Orton et al. 2008; Lee et al. 2010]. Nevertheless, no detailed procedures are currently available for designing end anchorage systems which necessitates further research in this area.

\section{CONCLUSION}

A review on plate-end debonding as a critical failure mode in FRP-strengthened RC beams was presented in this paper. Also, assessment of the available relevant prediction models was presented and discussed. The precautions recommended by the design codes and guides to avoid plate-end debonding were also assessed. The main conclusions drawn from this study are summarized as follows:

- Existing prediction models for PE debonding have been assessed by comparison with experimental database collected from the literature. The prediction models by the fib Bulletin 14, the Italian code CNR-DT 200, and that of Teng and Yao provide average results that are close to those from the experimental tests with the least scatter. This gives an indication that these formulations are the closest to being used as predictive models. The remaining models greatly underestimate the test results and lead to a large scatter with high coefficient of variations.

- For the beams where plate end debonding is the predominant mode of failure, extending FRP reinforcement close to the supports is not enough for avoiding such a failure mode.

- The $\mathrm{ACl} 440.2$ provision concerning terminating FRP reinforcement along the beam span at least a distance equal to the development length beyond the section corresponding to the cracking moment was verified against the collected database. The recommended provision appears to be successful in avoiding plate end debonding if it is considered in the design stage. 
- The shear force limits recommended by both $\mathrm{ACl} 440.2$ guidelines and fib Bulletin 14 for avoiding plate end debonding appear to be overly conservative and diminish the effectiveness of FRP strengthening. On the other hand, the limits suggested by both AS 5100.8 and TR55 are not successful for avoiding plate end debonding for the majority of the beams included in the database.

- Several anchorage techniques have been developed and investigated for the purpose of mitigating plate end debonding. However, no detailed design procedures for such anchorage systems are currently available. Further studies are required to fill this gap of knowledge.

\section{Acknowledgements}

The authors would like to thank Deanship of Scientific Research for funding and supporting this research through the initiative of DSR Graduate Students Research Support (GSRS) at King Saud University, Saudi Arabia.

Author's Contribuitions: Conceptualization, MA Al-Saawani, AK El-Sayed and Al Al-Negheimish; Methodology, MA Al-Saawani and AK El-Sayed; Investigation, MA Al-Saawani, AK El-Sayed and Al Al-Negheimish; Writing original draft, MA Al-Saawani and AK El-Sayed; Writing - review \& editing, AK El-Sayed and Al Al-Negheimish; Funding acquisition, Al Al-Negheimish; Resources, AK El-Sayed and Al Al-Negheimish; Supervision, AK El-Sayed and Al Al-Negheimish.

Editor: Marcílio Alves.

\section{References}

Achintha, M., Burgoyne, C.J., (2011). Fracture mechanics of plate debonding: Validation against experiment. Construction and Building Materials 25: 2961-2971.

$\mathrm{ACl}$ Committee 318 (2014). Building code requirements for structural concrete (ACl 318-14) and Commentary. American Concrete Institute, Farmington Hills, MI.

ACl Committee 440 (2017). Guide for the design and construction of externally bonded FRP systems for strengthening concrete structures ( $\mathrm{ACl}$ 440.2.). American Concrete Institute, Farmington Hills, Michigan.

Ahmed, O., (2000). Strengthening of R. C. beams by means of externally bonded CFRP laminates: Improved model for plateend shear. Ph.D. Thesis, Dept. of Civil Engineering, Catholicke University of Leuven, Belgium.

Ahmed, O., Van Gemert, D., (1999). Effect of longitudinal carbon fiber reinforced plastic laminates on shear capacity of reinforced concrete beams. In Proceedings of the fourth international symposium on fiber reinforced polymer reinforcement for reinforced concrete structures 933-943.

Al-Negheimish, A., El-Sayed, A., Al-Zaid, R., Shuraim, A., Alhozaimy, A., (2012). Behavior of wide shallow RC beams strengthened with CFRP reinforcement. Journal of Composites for Construction 16(4): 418-429.

Al-Saawani, M., El-Sayed, A., Al-Negheimish, A., (2015). Effect of basic design parameters on IC debonding of CFRPstrengthened shallow RC beams. Journal of Reinforced Plastics and Composites 2015; 34(18): 1526-1539.

Al-Tamimi, A., Hawileh, R.J., Rasheed, H., (2011). Effects of ratio of CFRP plate length to shear span and end anchorage on flexural behavior of SCC RC beams. Journal of Composites for Construction 15(6): 908-919.

Aprile A., Feo, L., (2007). Concrete cover rip-off of R/C beams strengthened with FRP composites. Composites Part B: Engineering 38(5): 759-771.

Arduini, M., Di Tommaso, A., Nanni, A., (1997). Brittle failure in FRP plate and sheet bonded beams. ACI Struct. J. 94(4): 363370.

AS 3600. (1988). Concrete structures. Standards Australia, SA1 Global Limited.

AS 5100.5 (2017). Bridge design, Part 5: Concrete. Standards Australia, SA1 Global Limited. 
AS 5100.8. (2017). Bridge design, Part 8: Rehabilitation and strengthening of existing bridges. Standards Australia, SA1 Global Limited.

Beber, A.J., Filho, A.C., Campagnolo, J.L., (1999). Flexural strengthening of R/C beams with CFRP sheets. In: Forde MC, editor. Proceedings of the Eighth International Conference on Advanced Composites for Concrete Repair, London, UK.

Benjeddou, O., Ouezdou, M.B., Bedday, A., (2007). Damaged RC beams repaired by bonding of CFRP laminates. Construction and Building Materials 21:1301-1310.

Brena, S.F., Bramblett, R.M., Wood, S.L., Kreger, M.E., (2003). Increasing flexural capacity of reinforced concrete beams using carbon fiber-reinforced polymer composites. ACI Structural Journal 100(1): 36-46.

BS EN 1992-1-1 (2004). Eurocode 2, Design of concrete structures-Part 1-1: General rules and rules for buildings. European Standard, European Committee for Standardization.

Buyukozturk, O., Gunes, O., Karaca, E., (2002). Characterization and modeling of debonding in RC beams strengthened with FRP composites. $15^{\text {th }}$ ASCE Engineering Mechanics Conference, Columbia University, New York: 1-8.

Ceroni, F., (2010). Experimental performances of RC beams strengthened with FRP materials. Construction and Building Materials 24: 1547-1559.

Ceroni, F., Pecce, M., Matthys, S., Taerwe, L., (2008). Debonding strength and anchorage devices for reinforced concrete elements strengthened with FRP sheets. Composites Part B: Engineering 39(3): 429-441.

Chen, J.F., Teng, J.G., (2001). Anchorage strength models for FRP and steel plates bonded to concrete. Journal of Structural Engineering ASCE 127(7): 784-791.

Chen, J.F., Teng, J.G., Yao, J., (2006). Strength model for intermediate crack debonding in FRP-strengthened concrete members considering adjacent crack interaction. Proceedings of Third International Conference on FRP Composites in Civil Engineering, Miami, Florida, USA: 67-70.

CNR. (2013). Guide for the design and construction of externally bonded FRP systems for strengthening existing structures. CNR-DT 200 R1, National Research Council, Rome, Italy.

Colotti, V., Spadea, G., Swamy, R.N., (2004). Structural model to predict the failure behavior of plated reinforced concrete beams. Journal of Composites for Construction ASCE 8(2): 104-122.

Concrete Society (2012). Design guidance for strengthening concrete structures using fibre composite materials. Concrete Society Technical Report No. 55, Crowthorne, UK.

David, E., Djelal, C., Ragneau, E., Bodin, F.B., (1999). Use of FRP to strengthen and repair RC beams: experimental study and numerical simulations. In: Forde MC, editor. Proceedings of the Eighth International Conference on Advanced Composites for Concrete Repair, London, UK.

Esfahani, M.R., Kianoush, M.R., Tajari, A.R., (2007). Flexural behavior of reinforced concrete beams strengthened by CFRP sheets. Engineering Structures 29: 2428-44.

Fanning, P.J., Kelly, O., (2001). Ultimate response of RC beams strengthened with CFRP plates. Journal of Composites for Construction ASCE 5(2): 122-7.

Gao, B., Kim, J.K., Leung, C.K.Y., (2004a). Taper ended FRP strips bonded to RC beams: Experiments and FEM analysis. In: Proceedings of the second international conference on FRP in civil engineering 399-405.

Gao, B., Kim, J.K., Leung, C.K.Y., (2004b). Experimental study on RC beams with FRP strips bonded with rubber modified resins. Composite Science and Technology 64: 2557-64.

Garden, H.N., Hollaway, L.C., Thorne, A.M., (1997). A preliminary evaluation of carbon fibre reinforced polymer plates for strengthening reinforced concrete members. Proceedings of the Institution of Civil Engineers: Structures and buildings 123 : 127-142.

Garden, H.N., Quantrill, R.J., Hollaway, L.C., Thorne, A.M., Parke, G.A.R., (1998). An experimental study of the anchorage length of carbon fiber composite plates used to strengthen reinforced concrete beams. Construction and Building Materials 12: 203-219.

GB-50608. (2010). Technical code for infrastructure application of FRP composites, China Planning Press, Beijing, China. 
Grace, N.F., Singh, S.B., (2005). Durability evaluation of carbon fiber-reinforced polymer strengthened concrete beams: Experimental study and design. ACI Structural Journal 102(1): 40-48.

Grelle, S.V., Sneed, L.H., (2013). Review of anchorage systems for externally bonded FRP laminates. International Journal of Concrete Structures and Materials 7(1): 17-33.

Hau, K.M., (1999). Experiments on concrete beams strengthened by bonding fibre reinforced plastic sheets. MSc in Civil Engineering Thesis. The Hong Kong Polytechnic University, Hong Kong, China.

Hasnat, A., (2014). Experimental investigation on flexural capacity of reinforced concrete beams strengthened with carbon fiber reinforced polymer strips. MSc thesis. Bangladesh University of Engineering and Technology, Bangladesh.

Hasnat, A., Islam, M., Amin, A., (2016). Enhancing the debonding strain limit for CFRP-strengthened RC beams using U-clamps: Identification of design parameters. Journal of Composites for Construction ASCE 20(1): 04015039-1-04015039-16.

International Federation for Structural Concrete (fib). (2001). Externally bonded FRP reinforcement for RC structures. Technical Rep., Task Group 9.3, Bulletin No. 14, Lausanne, Switzerland.

Jansze, W., (1997). Strengthening of RC members in bending by externally bonded steel plates. Ph.D. Thesis. Delft University of Technology.

Jeevan, N., Reddy, J., (2018) Strengthening of RC beams using externally bonded laminate (EBL) technique with end anchorages under flexure. Asian Journal of Civil Engineering 19: 263-272.

Kalfat, R., Al-Mahaidi, R., Smith, S.T., (2013). Anchorage devices used to improve the performance of reinforced concrete beams retrofitted with FRP composites: State-of-the-art review. Journal of Composites for Construction ASCE 17(1): 14-33.

Kotynia, R., Baky, H.A., Neale, K.W., Ebead, U.A., (2008). Flexural strengthening of RC beams with externally bonded CFRP systems: Test results and 3D nonlinear FE analysis. Journal of Composites for Construction ASCE 12(2): $190-201$.

Lee, J., Chacko, R., Lopez, M., (2010). Use of Mixed-Mode fracture interfaces for the modeling of large-scale FRP-strengthened beams. Journal of Composites for Construction ASCE 14(6): 845-855.

Lee, J., Lopez, M., (2016). Characterization of FRP U wrap anchors for externally bonded FRP-reinforced concrete elements: An experimental study. Journal of Composites for Construction ASCE 20(4): 04016012-1-04016012-11.

Li, X., Gu, X.L., Song, X.B., Ouyang, Y., Feng, Z.L., (2013). Contribution of U shaped strips to the flexural capacity of low-strength reinforced concrete beams strengthened with carbon fibre composite sheets. Composites Part B: Engineering 45: 117-126.

Lu, X.Z., Teng, J.G., Ye, L.P., Jiang, J.J., (2005). Bond-Slip models for FRP sheets/plates bonded to concrete. Engineering Structures 27(6): 920-937.

Lu, X.Z., Teng, J.G., Ye, L.P., Jiang, J.J., (2007). Intermediate crack debonding in FRP-strengthened RC beams: FE analysis and strength model. Journal of Composites for Construction ASCE 11: 161-174.

Maalej, M., Bian, Y., (2001). Interfacial shear stress concentration in FRP-strengthened beams. Composite Structures 54: 417426.

Matthys, S., (2000). Structural behavior and design of concrete beams strengthened with externally bonded FRP reinforcement. Ph.D. Thesis. Ghent University.

Mazzotti, C., Savoia, M., Ferracuti, B., (2008). An experimental study on delamination of FRP plates bonded to concrete. Construction and Building Materials 22(7): 1409-1421.

Nguyen, D.M., Chan, T.K., Cheong, H.K., (2001). Brittle failure and bond development length of CFRP-concrete beams. Journal of Composites for Construction ASCE 5(1): 12-17.

Oehlers, D.J., (1992). Reinforced concrete beams with plates glued to their soffits. Journal of Structural Engineering ASCE 118(8): 2023-2038.

Oehlers, D.J., Liu, I.S.T., Seracino, R., (2005). Shear deformation debonding of adhesively bonded plates. Proceedings of the Institution of Civil Engineers: Structures and Buildings 158(1): 77-84.

Oehlers, D.J., Liu, I.S.T., Seracino, R., Mohamed Ali, M.S., (2004). Prestress model for shear deformation debonding of FRP- and steel-plated RC beams. Magazine of Concrete Research 56(8): 475-486. 
Orton, S.L., Jirsa, J.O., Bayrak, O., (2008). Design considerations of carbon fiber anchors. Journal of Composites for Construction ASCE 12(6): 608-616.

Pham, H.B., Al-Mahaidi, R., (2006). Prediction models for debonding failure loads of carbon fiber reinforced polymer retrofitted reinforced concrete beams. Journal of Composites for Construction ASCE 10(1): 48-59.

Pimanmas, A., Pornpongsaroj, P., (2004). Peeling behaviour of reinforced concrete beams strengthened with CFRP plates under various end restraint conditions. Magazine of Concrete Research 56(2): 73-81.

Quantrill, R.J., Hollaway, L.C., Thorne, A.M., (1996a). Experimental and analytical investigation of FRP strengthened beam response: Part I. Magazine of Concrete Research 48(177): 331-342.

Quantrill, R.J., Hollaway, L.C., Thorne, A.M., (1996b). Predictions of the maximum plate end stresses of FRP strengthened beam: Part II. Magazine of Concrete Research 1996b; 48(177): 343-351.

Rahimi, H., Hutchinson, A., (2001). Concrete beams strengthened with externally bonded FRP plates. Journal of Composites for Construction ASCE 5(1):44-56.

Raoof, M., Zhang, S., (1997). An insight into the structural behavior of reinforced concrete beams with externally bonded plates. Proceedings of the Institution of Civil Engineers: Structures and Buildings 122(4): 477-492.

Raoof, M., Hassanen, M.A.H., (2000). Peeling failure of reinforced concrete beams with fibre-reinforced plastic or steel plates glued to their soffits. Proceedings of the Institution of Civil Engineers: Structures and Buildings 140: 291-305.

Ritchie, P.A., Thomas, D.A., Lu, L.W., Conelly, G.M., (1991). External reinforcement of concrete beams using fibre reinforced plastics. ACI Structural Journal 88(4): 490-500.

Rosenboom, O., Rizkalla, S., (2008). Experimental study of intermediate crack debonding in fiber-reinforced polymer strengthened beams. ACl Structural Journal 105(1): 41-50.

Ross, C.A., Jerome, D.M., Tedesco, J.W., Hughes, M.L., (1999). Strengthening of reinforced concrete beams with externally bonded composite laminates. ACI Structural Journal 96(2):212-220.

Sadrmomtazi, A., Rasmi Atigh, H., Sobhan, J., (2014). Experimental and analytical investigation on bond performance of the interfacial debonding in flexural strengthened RC beams with CFRP sheets at tensile face. Asian Journal of Civil Engineering (BHRC) 15(3): 391-410.

Sebastian, W.M., (2001). Significance of mid span debonding failure in FRP-plated concrete beams. Journal of Structural Engineering ASCE 127(7): 792-798.

Skuturna, T., Valivonis, J., (2016). Experimental study on the effect of anchorage systems on RC beams strengthened using FRP. Composites Part B 91: 283-290.0

Smith, S.T., Teng, J.G., (2003). Shear-bending interaction in debonding failures of FRP-plated RC beams. Advances in Structural Engineering 6(3): 183-199.

Smith, S.T., Teng, J.G., (2002a). FRP-strengthened RC beams. Part I: Review of debonding strength models. Engineering Structures 24:385-95.

Smith, S.T., Teng, J.G., (2002b). FRP-strengthened RC beams. Part II: Assessment of debonding strength models. Engineering Structures 24: 397-417.

Spadea, G., Bencardino, F., Swamy, R.N. (1998). Structural behavior of composite RC beams with externally bonded CFRP. Journal of Composites for Construction ASCE 2(3): 132-139.

Täljsten, B., (1997). Defining anchor lengths of steel and CFRP plates bonded to concrete. International Journal of Adhesion and Adhesives 17(4): 319-327.

Teng, J.G., Cao, S.Y., Lam, L., (2001). Behaviour of GFRP-strengthened RC cantilever slabs. Constr. and Build. Mat. 2001; 15(7): 339-349.

Teng, J.G., Chen, J.F., (2007). Debonding failures of RC beams strengthened with externally bonded FRP reinforcement: Behaviour and modelling. Asia-Pacific Conference on FRP in Structures 33-42.

Teng, J.G., Chen, J.F., Smith, S.T., Lam L., (2002). FRP strengthened RC structures. England: John Wiley \& Sons, Ltd. 
Teng, J.G., Smith, S.T., Chen, J.F., (2003). Intermediate crack-induced debonding in RC beams and slabs. Construction and Building Materials 17: 447-462.

Teng, J.G., Yao, J., (2007). Plate end debonding in FRP-plated RC beams-II: Strength model. Engineering Structures 29: 24722486.

Tumialan, G., Serra, P., Nanni, A., Belarbi, A., (1999). Concrete cover delamination in reinforced concrete beams strengthened with carbon fiber reinforced polymer sheets. In: Dolan CW, Rizkalla SH, Nanni A, editors. Proceedings of the Fourth International Symposium on Fiber Reinforced Polymer Reinforcement for Reinforced Concrete Structures, Maryland, USA, 725-735.

Valcuende, M., Benlloch, J., Parra, C.J., (2003). Ductility of reinforced concrete beams strengthened with CFRP strips and fabric. In: Proceedings of the sixth international symposium on FRP reinforcement for concrete structures 337-346.

Wu, Z.S., Niu, H.D., (2000). Study on debonding failure load of RC beams strengthened with FRP sheets, Journal of Structural Engineering ASCE 105(46A): 1431-1441.

Yao. J., (2004). Debonding failures in reinforced concrete structures strengthened with externally bonded FRP sheets/plates. Ph.D. Thesis, the Hong Kong Polytechnic University, Hong Kong, China.

Yao, J., Teng, J.G., (2007). Plate end debonding in FRP-plated RC beams-I: Experiments. Engineering Structures 29: 24572471.

Yao, J., Teng, J.G., Lam, L., (2002). Debonding in RC cantilever slabs strengthened with FRP strips. In: Proceedings of the international conference on advanced polymer composite for structural applications in construction, Southampton University, UK 125-133.

Zhang, D., Ueda, T., Furuuchi, H., (2012). Concrete cover separation failure of overlay-strengthened reinforced concrete beams. Construction and Building Materials 26: 735-745.

Zhang, S.S., (2011). Behaviour and modelling of RC beams strengthened in flexure with near-surface mounted FRP. Ph.D. Thesis, the Hong Kong Polytechnic University, Hong Kong, China.

Zhang, S.S., Teng, J.G., (2014). Finite element analysis of end cover separation in RC beams strengthened in flexure with FRP. Engineering Structures 75:550-560.

\section{Notation}

The following symbols are used in this paper:

$A_{s}=$ cross-sectional area of tension steel reinforcement;

$A_{v}=$ cross-sectional area of shear reinforcement provided by steel stirrups;

$A_{s v}=$ cross-sectional area of steel stirrups;

$a_{v}=$ shear span of the test beam;

$a^{\prime}{ }_{v}=$ modified shear span of the beam;

$b_{a}=$ width of adhesive layer;

$b_{c}=$ width of concrete beam;

$b_{f}=$ width of FRP;

$C_{c}=$ concrete cover thickness;

$c_{1}$ and $c_{2}=$ factors for CFRP strips;

$d_{s}=$ effective depth of tension steel;

$E_{c}=$ elastic modulus of concrete;

$E_{f}=$ tensile modulus of elasticity of FRP reinforcement;

$E_{s v}=$ tensile modulus of elasticity of steel stirrups;

$(E I)_{o, c}=$ flexural rigidity of the cracked section without EB FRP;

$(E I)_{f, c}=$ flexural rigidity of the cracked section with EB FRP;

$f_{c}^{\prime}=$ specified compressive strength of concrete;

$f_{c k}=$ characteristic strength of concrete;

$f_{c t}=$ tensile strength of concrete;

$f_{y}=$ yield strength of the steel reinforcement;

$f_{y v}=$ yield strength of the steel stirrups;

$k_{b}=$ geometric coefficient; 
$k_{c}=\mathrm{a}$ factor for concrete compaction;

$k_{G}=$ corrective factor taken for pre-cured FRP;

$I_{c}=$ second moment of area of strengthened equivalent cracked section;

$I_{a}=$ FRP distance from its end to the section where it is fully utilized;

$I_{b}=$ bond length of FRP reinforcement;

$I_{b, \max }=$ the maximum anchorage length of FRP reinforcement;

$I_{c}=$ crack spacing;

$L_{e}=$ effective bond length of FRP;

$L_{d f}=$ development length of FRP reinforcement;

$L_{u p}=$ unplated length of FRP reinforcement;

$M_{c r}=$ cracking moment;

$M_{d b, f}=$ flexural debonding moment of FRP plate end located in a pure bending region;

$M_{u, o}=$ theoretical ultimate moment of the un-plated section;

$n_{f}=$ number of FRP plies;

$P_{u, \text { exp }}=$ experimental load capacity of the test beams;

$P_{u, c a l}=$ calculated load capacity;

$s_{c}=$ width of the tie element;

$s_{v}=$ spacing of the steel stirrups;

$t_{f}=$ thickness of a single ply of FRP reinforcement;

$T_{f, \max }=$ maximum tensile load at the end of the FRP reinforcement;

$U_{y}=$ limiting bond strength factor;

$V_{c}=$ shear capacity provided by concrete;

$V_{d b, s}=$ debonding shear force at FRP plate end located in a region of nearly zero moment;

$V_{d b, \text { end }}=$ critical shear force at the FRP plate end which causes debonding;

$V_{\text {exp }}=$ experimental shear load at debonding failure;

$V_{f}=$ shear capacity provided by FRP;

$V_{\text {limit }}=$ the limit of the shear force;

$V_{R d}=$ shear strength of the concrete section;

$V_{s}=$ shear capacity provided by steel stirrups;

$\overline{V_{s}}=$ shear force carried by the shear steel reinforcement per unit strain;

$V^{*}=$ factored shear force at the FRP plate end;

$X_{c r}=$ the point along the span at which the resisted moment corresponds to the cracking moment;

$B_{1}=$ factor representing the effect of the bond length of the EB FRP;

$B_{w}=$ factor related to the effect of width ratio between the EB FRP and concrete;

$\alpha=$ a coefficient for mean and characteristic values;

$\alpha_{f l e x}=$ parameter for flexural rigidity of the beam;

$\alpha_{a x i a l}=$ parameter for axial rigidity of the beam;

$\alpha_{w}=$ parameter for the ratio of the beam width to the FRP width;

$\varepsilon_{f d}=$ debonding strain of FRP reinforcement;

$\varepsilon_{v, e}=$ effective strain in the shear steel reinforcement;

$\gamma_{f, d}=$ concrete partial coefficient;

$\rho_{s}=$ tension steel reinforcement ratio,

$\phi_{s}=$ diameter of tension steel reinforcement;

$\Gamma_{f, d}=$ design value of the specific fracture energy of the FRP-concrete interface. 